
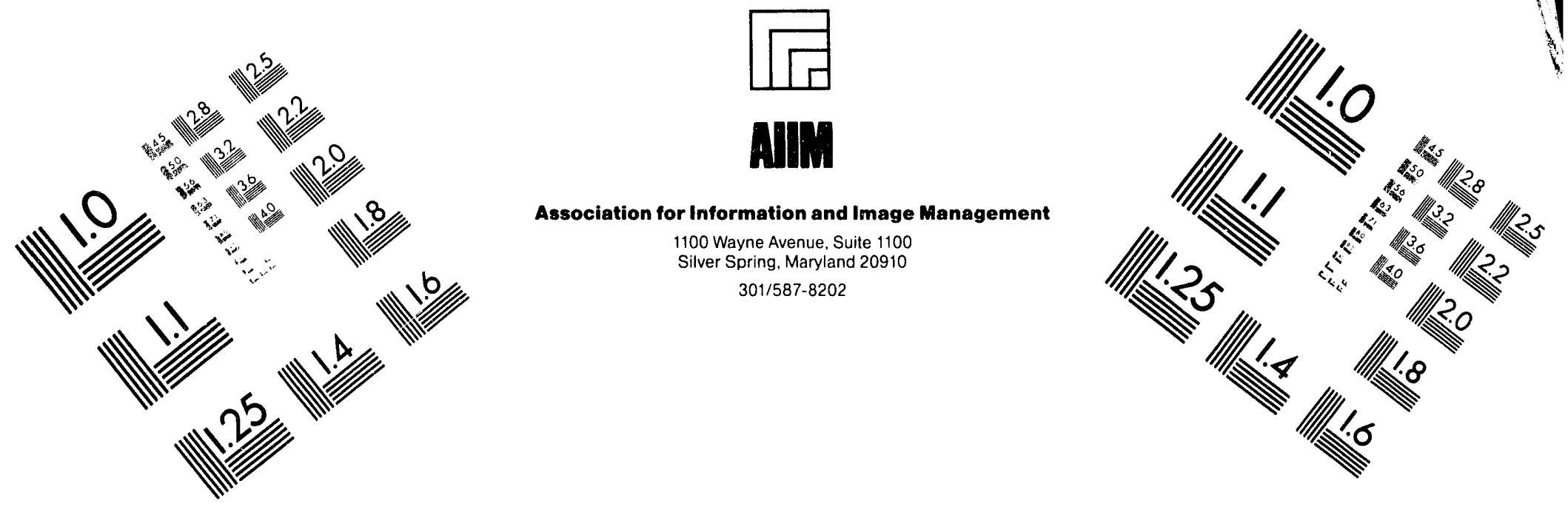

Centimeter

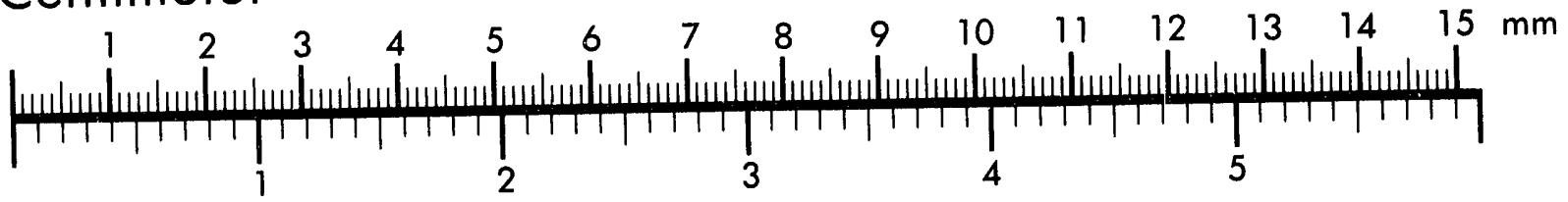
Inches
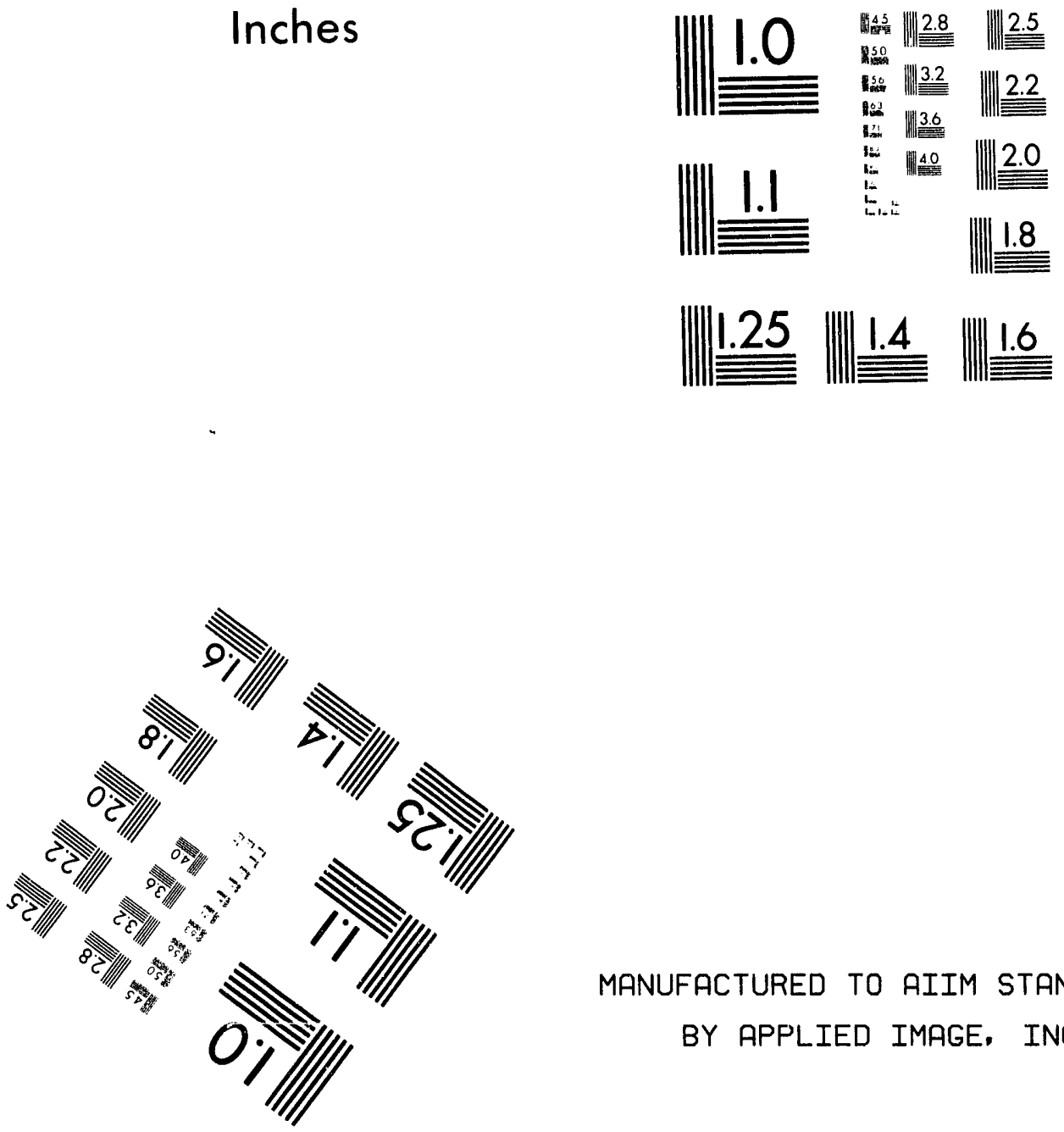

MANUFACTURED TO AIIM STANDARDS

BY APPLIED IMAGE, INC.

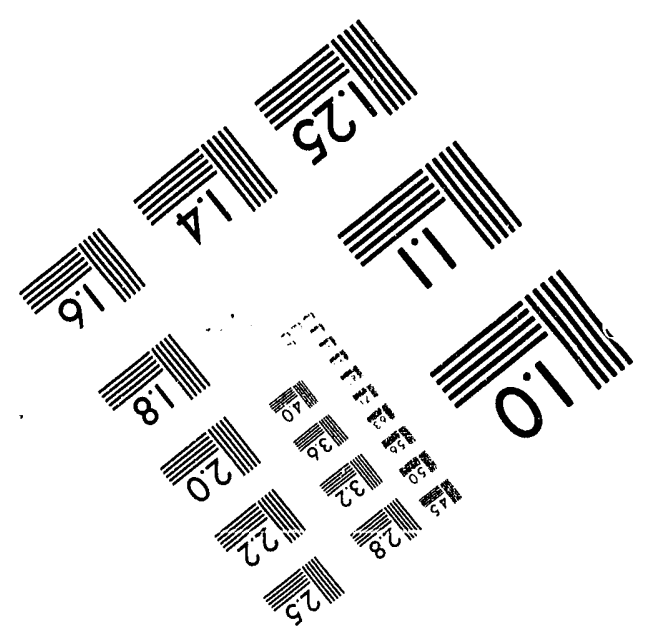



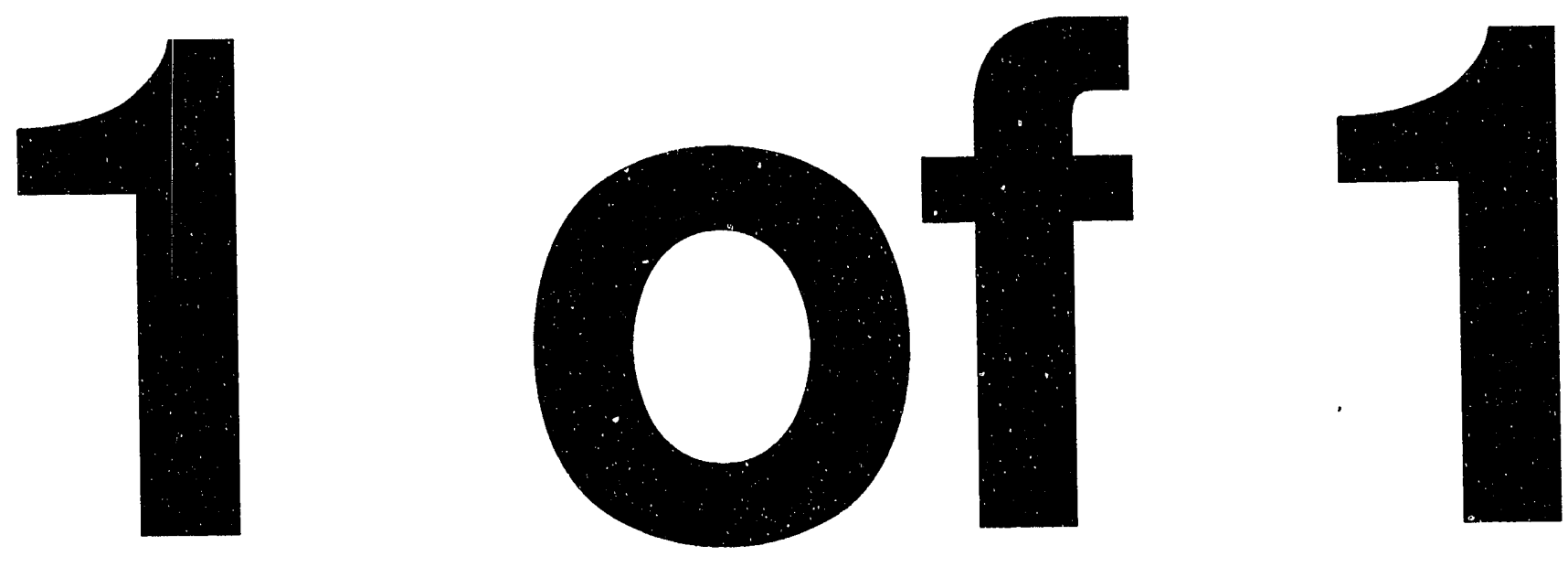
ORNL/TM-12399

Chemical Technology Division

\section{RECOVERY AND PURIFICATION OF NICKEL-63 \\ FROM HFIR-IRRADIATED TARGETS}

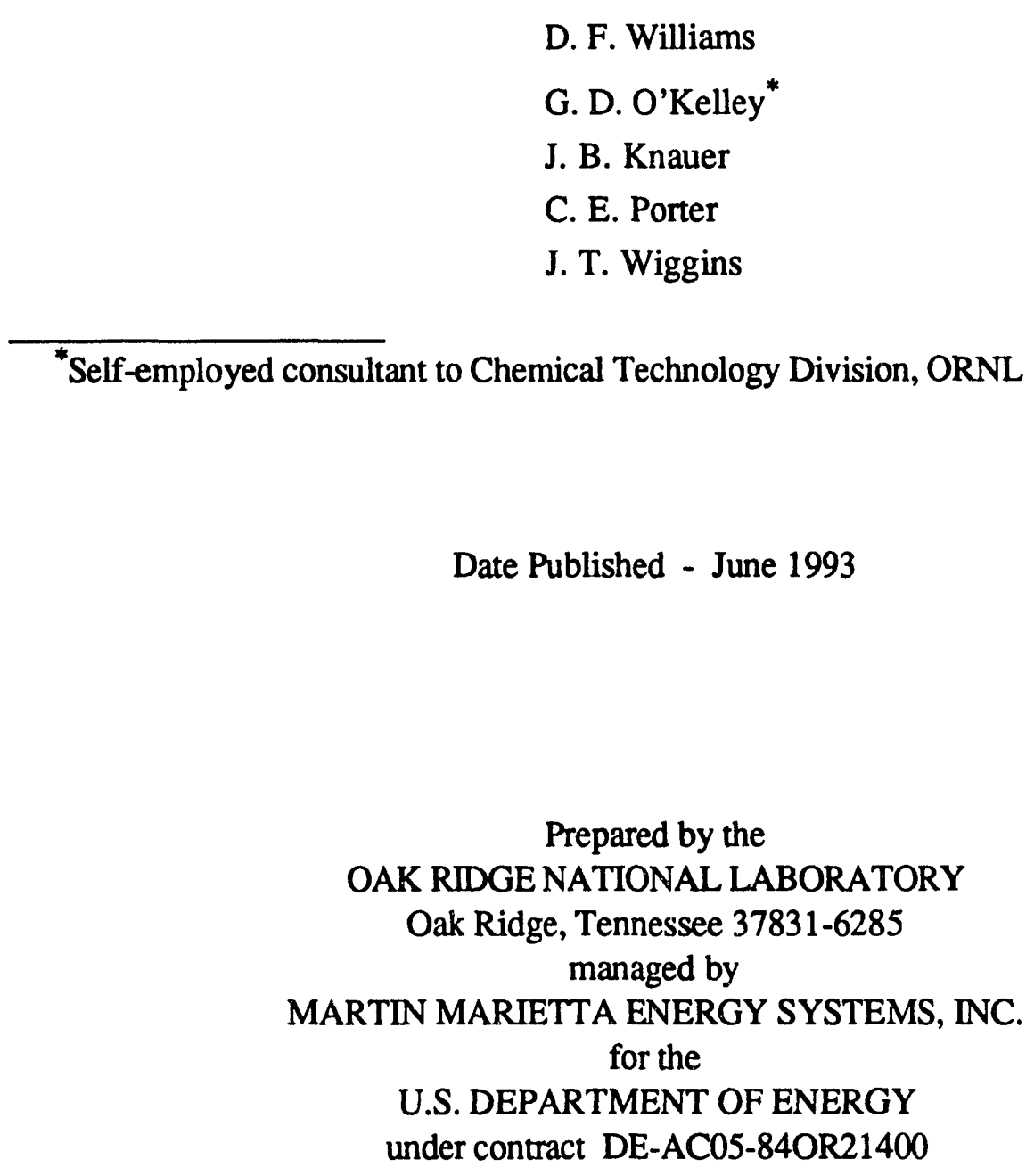




\section{CONTENTS}

FIGURES

TABLES vii

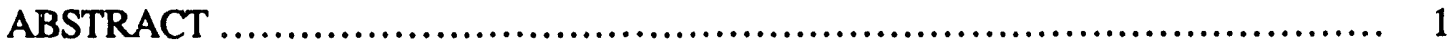

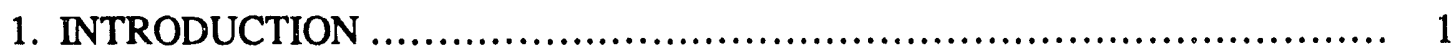

2. FLOWSHEET OVERVIEW ................................................. 4

3. DESCRIPTION OF INDIVIDUAL OPERATIONS ............................ 9

3.1 TARGET HANDLING AND SECTIONING ............................... g

3.2 TARGET LEACHES AND DISSOLUTIONS ............................. 9

3.2.1 Aluminum Removal................................................. 9

3.2.2 Nickel Dissolution.................................................... 11

3.3 NICKEL PURIFICATION ............................................. 13

3.3.1 Anion-Exchange Removal of Transition Metals ....................... 13

3.3.2 Cation-Exchange Removal of Scandium ............................ 18

3.3.3 Chromium Removal by TOPO Extraction.............................. 19

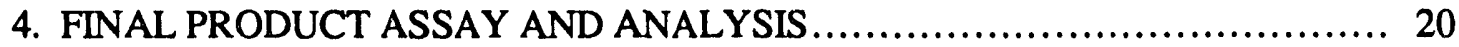

4.1 FINISHED PRODUCT DESCRIPTION ............................... 20

4.2 TOTAL NICKEL DETERMINATION BY ABSORPTION SPECTROPHOTOMETRY ................................................ 20

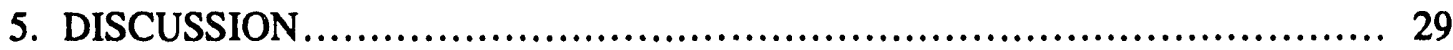

5.1 IMPROVED FLOWSHEET POSSIBILITIES ............................ 29

5.2 EVALUATION OF TARGET AND PELLET LEACHES .................... 32

ACKNOWLEDGMENTS....................................................... 39

REFERENCES................................................................ 41

Appendix A. DIAGRAM OF INDEXING JIG FOR SECTIONING ${ }^{63} \mathrm{Ni}$ TARGETS ...................................................... 43

Appendix B. SUMMARY OF TARGET LEACHING RESULTS................. 51

Appendix C. ALUMINUM DISSOLUTION BASIS ........................ 55

Appendix D. SUMMARY OF NICKEL PELLET LEACHING RESULTS ......... 59 


\section{FIGURES}

1 Anion-exchange behavior of the elements in $\mathrm{HCl}$ solutions on Dowex-1 resin.

2 Flowsheet for ${ }^{63} \mathrm{Ni}$ processing............................................6 6

3 Schematic of HFIR target for ${ }^{63} \mathrm{Ni}$ production.............................. 7

4 Equipment diagram for in-cell processing.................................. 8

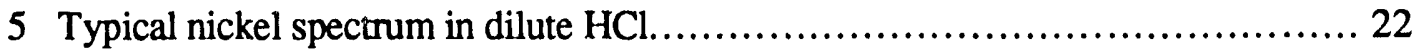

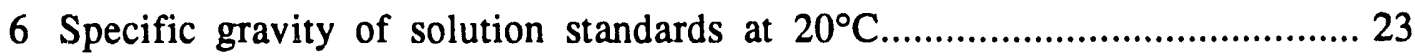

7 Beer's law plot of solution standards. ....................................... 25

8 Beer's law plot for nickel standards measurement, target A.......................... 26

9 Beer's law plot for nickel standards measurement, target B......................... 27

10 Spectra of nickel product solution. ........................................... 28

11 Distribution coefficients of $\mathrm{Ni}(\mathrm{II}), \mathrm{Mn}(\mathrm{II}), \mathrm{Cr}(\mathrm{III})$, and $\mathrm{Na}(\mathrm{I})$ in $\mathrm{HNO}_{3}$ solutions on cation-exchange resin (Dowex 50W-X4) ............................... 30

12 Ratio of distribution coefficients for $\mathrm{Ni}$ (II) and $\mathrm{Cr}$ (III) in $\mathrm{HNO}_{3}$ and $\mathrm{HCl}$ solutions on cation-exchange resin (Dowex 50W-X4).............................. 31

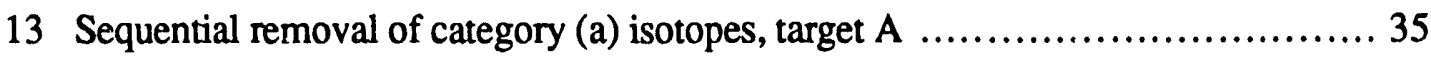

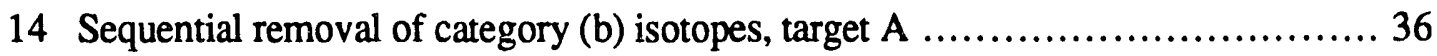

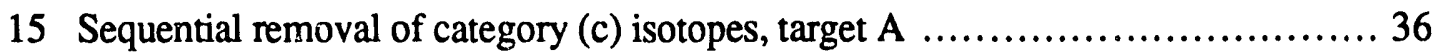

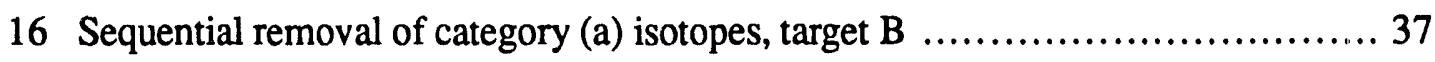

17 Sequential removal of category (b) isotopes, target B ......................... 38

A.1 Diagram of indexing jig for sectioning ${ }^{63} \mathrm{Ni}$ targets. ......................... 45 


\section{TABLES}

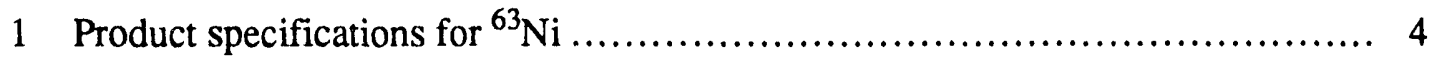

2 Important impurities and associated activation products in nickel pellets.......... 5

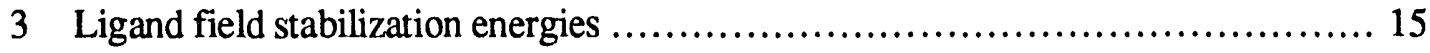

4 Results from second anion-exchange cold test............................... 16

5 Results for the purification of nickel (target A) ............................. 17

6 Results for the purification of nickel (target B) .............................. 18

7 Physical, chemical, radiochemical, and isotopic description of ${ }^{63} \mathrm{Ni}$ products....... 21

$8 \mathrm{NiCl}_{2}$ solution standards (in $0.1 \mathrm{M} \mathrm{HCl}$ ) ................................. 23

9 Absorbance measurements on solution standards ............................... 24

10 Glove box absorbance measurements......................................... 26

11 Product nickel concentrations (in molarity) based upon absorbance measurements .................................................................. 28

12 Chromium(VI) removal by ion exchange................................... 32

13 Total activity (in millicuries) removed by target and pellet leaches ................ 33

B.1 Segment leaching results (in millicuries), target A................................. 53

B.2 Segment leaching results (in millicuries), target B................................. 53

C.1 Inventory of aluminum and alloying elements in sectioned target segments ........ 57

D.1 Results from acid leaches of nickel pellets (in millicuries), target A.................. 61

D.2 Results from acid leaches of nickel pellets (in millicuries), target B................. 61

D.3 Gross-alpha measurements on target $\mathrm{A}$ leaches............................ 62 


\title{
RECOVERY AND PURIFICATION OF NICKEL-63 \\ FROM HFIR-IRRADIATED TARGETS
}

\author{
D. F. Williams, G. D. O'Kelley, J. B. Knauer, C. E. Porter, and J. T. Wiggins
}

\begin{abstract}
The production of large quantities of high-specific-activity ${ }^{63} \mathrm{Ni}(>10 \mathrm{Ci} / \mathrm{g})$ requires both a highly enriched ${ }^{62} \mathrm{Ni}$ target and a long irradiation period at high neutron flux. Trace impurities in the nickel and associated target materials are also activated and account for a significant fraction of the discharged activity and essentially all of the gamma activity. While most of these undesirable activation products can be removed as chloride complexes during anion exchange, chromium, present as ${ }^{51} \mathrm{Cr}$, and scandium, present as ${ }^{46} \mathrm{Sc}$, are exceptions and require additional processing to achieve the desired purity. Optimized flowsheets are discussed based upon the current development and production experience.
\end{abstract}

\section{INTRODUCTION}

The purpose of this report is to summarize the important elements of a special project for recovery and purification of ${ }^{63} \mathrm{Ni}$ from targets irradiated in the High Flux Isotope Reactor (HFIR) located at Oak Ridge National Laboratory (ORNL). This work was undertaken by the staff of the Process Development Group of the Radiochemical Engineering Development Center (REDC) at ORNL. As is the case with most new projects, some degree of development was also necessary during the first cycle of operations. The flowsheet presented in this report is the result of both preliminary and operational development work.

Nickel-63 is readily electroplated $[1,2]$ and is one of the few isotopes that decays solely by $\beta^{-}$emission $\left(t_{1 / 2} \sim 100 \mathrm{y}\right.$ ), making it especially well suited as a source for electron-capture detectors [3] and other applications $[4,5]$ with an exclusive need for lowenergy $(<67-\mathrm{keV})$ electrons. Since the other isotopes of nickel are either stable $(A=58$, $60,61,62$, and 64$)$, short-lived $\left(A=65, t_{1 / 2}=2.5 \mathrm{~h}\right)$, or very long-lived $\left(A=59, t_{1 / 2}=\right.$ $76,000 \mathrm{y}),{ }^{63} \mathrm{Ni}$ remains as the only useful nickel isotope of intermediate half-life. While the relatively large $(n, \gamma)$ cross section of ${ }^{62} \mathrm{Ni}\left(\sigma_{\text {thermal }}=15\right.$ barns) provides for a practical 
production path, its low natural abundance $(3.6 \%)$ requires targets that are isotopically enriched.

The radiochemical purification of nickel has been achieved by exploiting either (a) the highly selective precipitation of nickel with dimethylglyoxime $[6,7]$ or (b) the complete absence of nickel sorption from $\mathrm{HCl}$ solutions on anion exchange resin, an exception to the typical strong sorption behavior of the transition metals [8, 9]. Besides palladium, only nickel forms a chelate compound with dimethylglyoxime and is selectively removed by precipitation in ammoniacal solution. This separation process produces a voluminous, amorphous nickel-precipitate. While this manner of purification has been refined [6] and carried out on large quantities of nickel [7], it requires extensive washing and handling of solids and was judged as a difficult and risky hot-cell operation (especially given the cross-contamination hazards present in the cell bank).

While not as specific a separation as dimethylglyoxime precipitation, anionexchange purification of $\mathrm{Ni}(\mathrm{II})$ in $9 \underline{\mathrm{M} \mathrm{HCl}}$ has many desirable features. A separations scheme based upon anion exchange offers the opportunity to purify nickel by a series of simple fluid operations which are easily adapted to hot-cell operations and provide for isolation from cell contamination. The well-known adsorption chart of Kraus and Nelson [9], reproduced in Fig. 1, shows that, with the exception of $\mathrm{Ni}(\mathrm{II})$, all of the transition metals form anionic chloride-complexes and are sorbed to varying degrees upon Dowex-1 resin. Ni(II) "pours" through the anion-exchange column, exhibiting essentially no affinity for adsorption. In this manner, most of the common transition metal contaminants can be removed in a relatively small resin bed.

The balance of the flowsheet addresses both (a) the early processing steps, targeted at limiting the amount of contamination and undesirable activation products entrained into the dissolved nickel, and (b) the final processing necessary to complement the anionexchange purification of nickel.

\footnotetext{
${ }^{*} \mathrm{The}{ }^{63} \mathrm{Cu}(n, p)$ pathway has the potential for generating higher nickel specific activities without requiring enriched material; however, the yields are extremely low.
} 

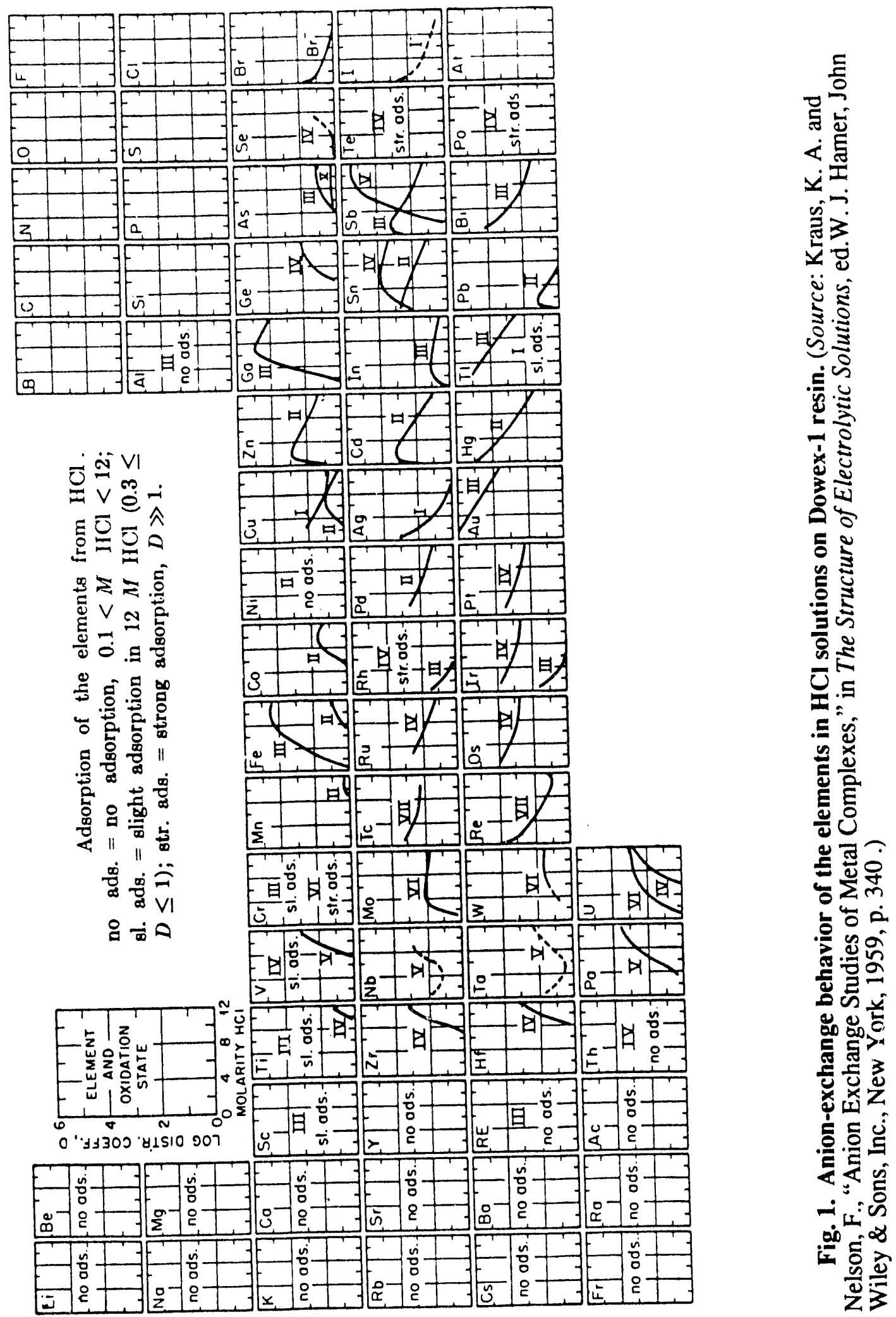


\section{FLOWSHEET OVERVIEW}

The product specifications listed in Table 1 and the radiochemical impurities summarized in Table 2 served as the basis for developing a flowsheet (Fig. 2) to recover and purify ${ }^{63} \mathrm{Ni}$ from two different irradiated targets. The physical form of the starting material was essentially the same for both batches (denoted $\mathrm{A}$ and $\mathrm{B}$ ): $\sim 12 \mathrm{~g}$ of nickel pellets encapsulated in a standard HFIR target [10], as shown in Fig. 3. Based upon the activation products displayed in Table 2 , it is clear that transition metal separations will dominate the flowsheet. However, the ${ }^{46} \mathrm{Sc}$ activation also constitutes a considerable gamma source and must be removed before hands-on (i.e., glove box) work can begin. The processing consists of three major steps: (a) target dissolution, (b) nickel purification, and (c) product analysis. Although the primary focus of this paper is on the purification steps, the brief description of the complete flowsheet that follows highlights those preliminary steps which also help ensure product purity.

Table 1. Product specifications for ${ }^{63} \mathrm{Ni}$

\begin{tabular}{cc}
\hline${ }^{63} \mathrm{Ni}$ specific activity & $>10 \mathrm{Ci}{ }^{63} \mathrm{Ni}$ per gram of nickel element \\
Alpha activity / ${ }^{63} \mathrm{Ni}$ activity \\
Radionuclidic purity \\
(nonnickel activity / ${ }^{63} \mathrm{Ni}$ activity) \\
Chemical purity & $<3 \times 10^{-10}$ \\
Solution concentration & $>0.001 \%$ \\
\hline
\end{tabular}

Prior to the dissolution step, the target is sectioned into convenient lengths, and a set of leaches is performed to remove any surface contamination that may have been introduced during irradiation or handling within the cell bank. The outer aluminum jacket is removed from the cleaned segments by a standard caustic dissolution [11], leaving just the nickel pellets and a small dissolution heel as solids. The powdery heel is removed from the nickel by a series of rinses/leaches with dilute caustic, water, and dilute $\mathrm{HCl}$. Finally, the cleaned nickel pellets are dissolved in nitric acid. The simple laboratory equipment used for the 
Table 2. Important impurities and associated activation products in nickel pellets

\begin{tabular}{|c|c|c|c|c|c|}
\hline \multirow[b]{2}{*}{$\begin{array}{l}\text { Elemental } \\
\text { impurities }\end{array}$} & \multirow[b]{2}{*}{$\begin{array}{l}\text { Activated } \\
\text { isotopes }\end{array}$} & \multicolumn{2}{|c|}{ Target A } & \multicolumn{2}{|c|}{ Target B } \\
\hline & & $\begin{array}{c}\text { Reported } \\
\text { impurity level } \\
\text { in feed } \mathrm{Ni} \\
\text { (wt \%) }\end{array}$ & $\begin{array}{l}\text { Measured } \\
\text { activation } \\
(\mathrm{mCi})^{a, b}\end{array}$ & $\begin{array}{c}\text { Reported } \\
\text { impurity level } \\
\text { in feed } \mathrm{Ni} \\
(\text { wt } \%)\end{array}$ & $\begin{array}{l}\text { Measured } \\
\text { activation } \\
(\mathrm{mCi})^{a, c}\end{array}$ \\
\hline $\mathrm{Ca}$ & ${ }^{46} \mathrm{Sc}$ & 0.033 & 25 & 0.005 & 0.5 \\
\hline $\mathrm{Cr}$ & ${ }^{51} \mathrm{Cr}$ & 0.032 & 675 & 0.004 & 5 \\
\hline $\mathrm{Fe}$ & $\begin{array}{l}{ }^{54} \mathrm{Mn} \\
{ }^{59} \mathrm{Fe}\end{array}$ & - & $\begin{array}{l}0.2 \\
57\end{array}$ & $<0.003$ & $\begin{array}{l}0.07 \\
15\end{array}$ \\
\hline Co & $\begin{array}{l}{ }^{58} \mathrm{Co} \\
{ }^{60} \mathrm{Co}\end{array}$ & - & $\begin{array}{r}89 \\
125\end{array}$ & $<0.005$ & $\begin{array}{l}18 \\
24\end{array}$ \\
\hline $\mathrm{Cu}$ & ${ }^{65} \mathrm{Zn}$ & - & - & 0.008 & - \\
\hline $\mathrm{Zn}$ & ${ }^{65} \mathrm{Zn}$ & - & 7 & 0.005 & 17 \\
\hline $\mathrm{Cd}$ & ${ }^{110 \mathrm{~m}} \mathrm{Ag}$ & - & - & $<0.003$ & 0.1 \\
\hline $\mathrm{Sn}$ & ${ }^{124} \mathrm{Sb}$ & - & - & $<0.001$ & 2 \\
\hline
\end{tabular}

${ }^{a}$ Derived from analysis of dissolved nickel.

${ }^{b}$ Four weeks after eight-cycle irradiation of target A.

${ }^{c}$ Eleven weeks after four-cycle irradiation of target B. 


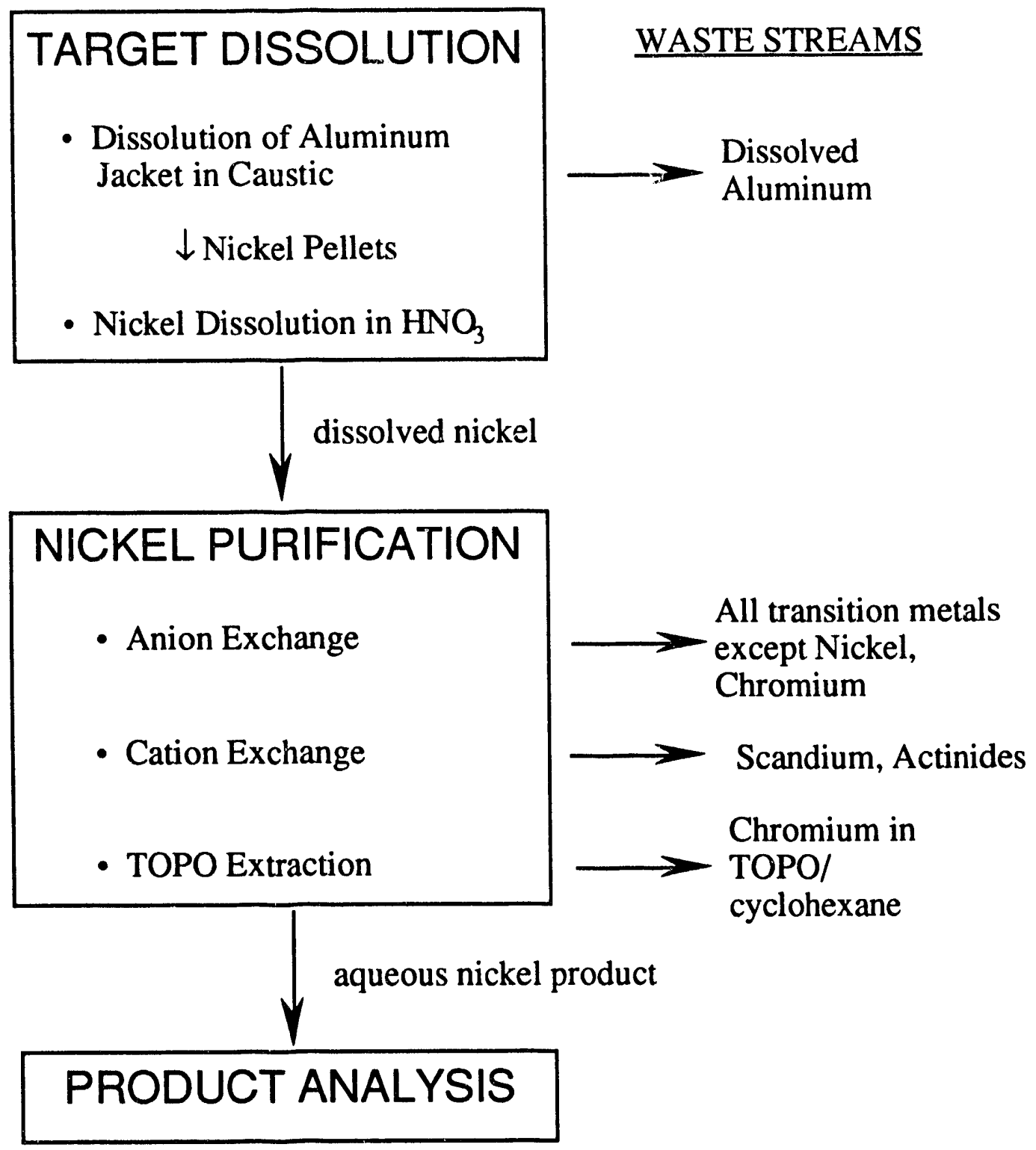

Fig. 2. Flowsheet for ${ }^{63} \mathrm{Ni}$ processing. 

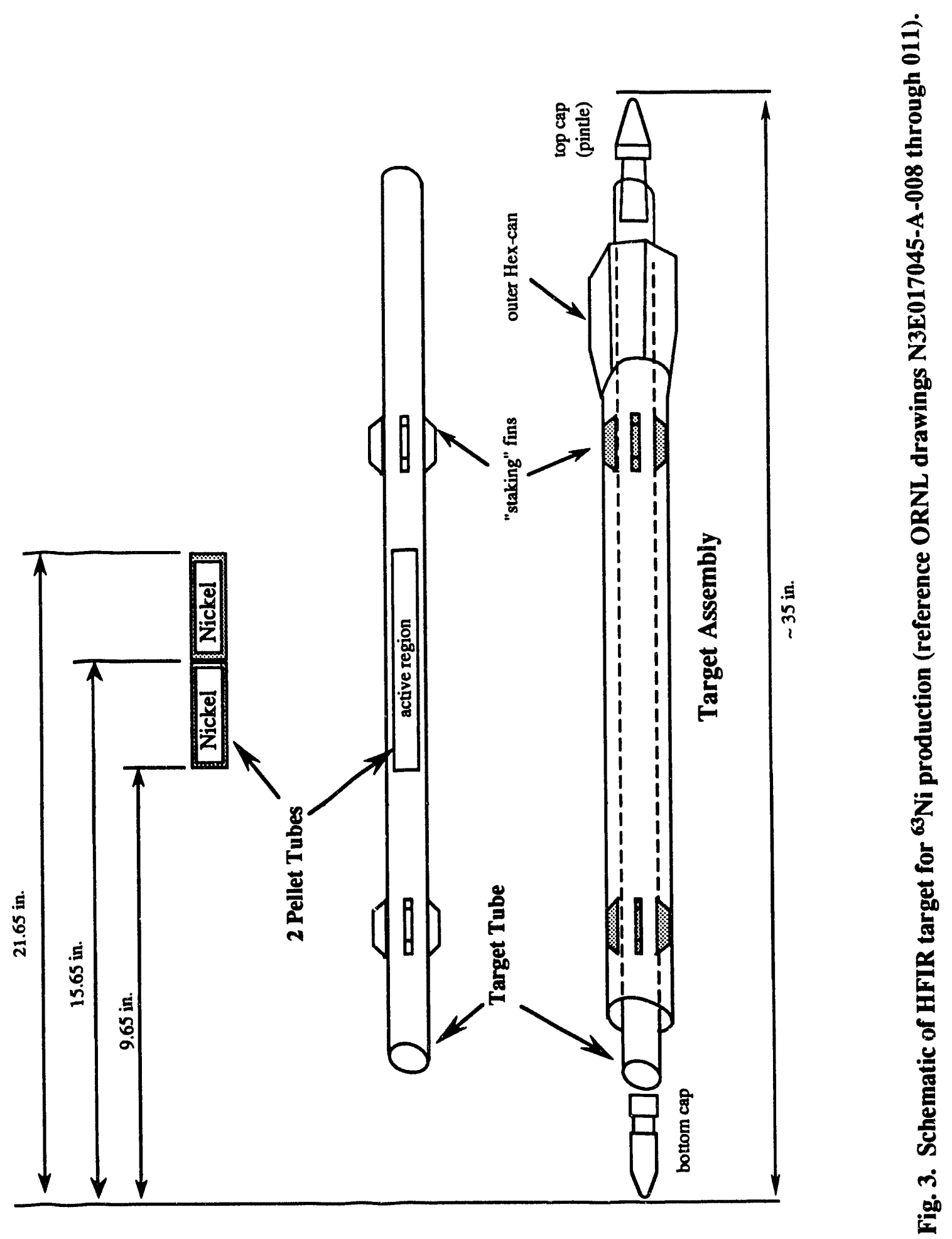
dissolution and in-cell purification steps provided for enclosed fluid operations and isolated the nickel from the considerable surface contamination present (Fig. 4).

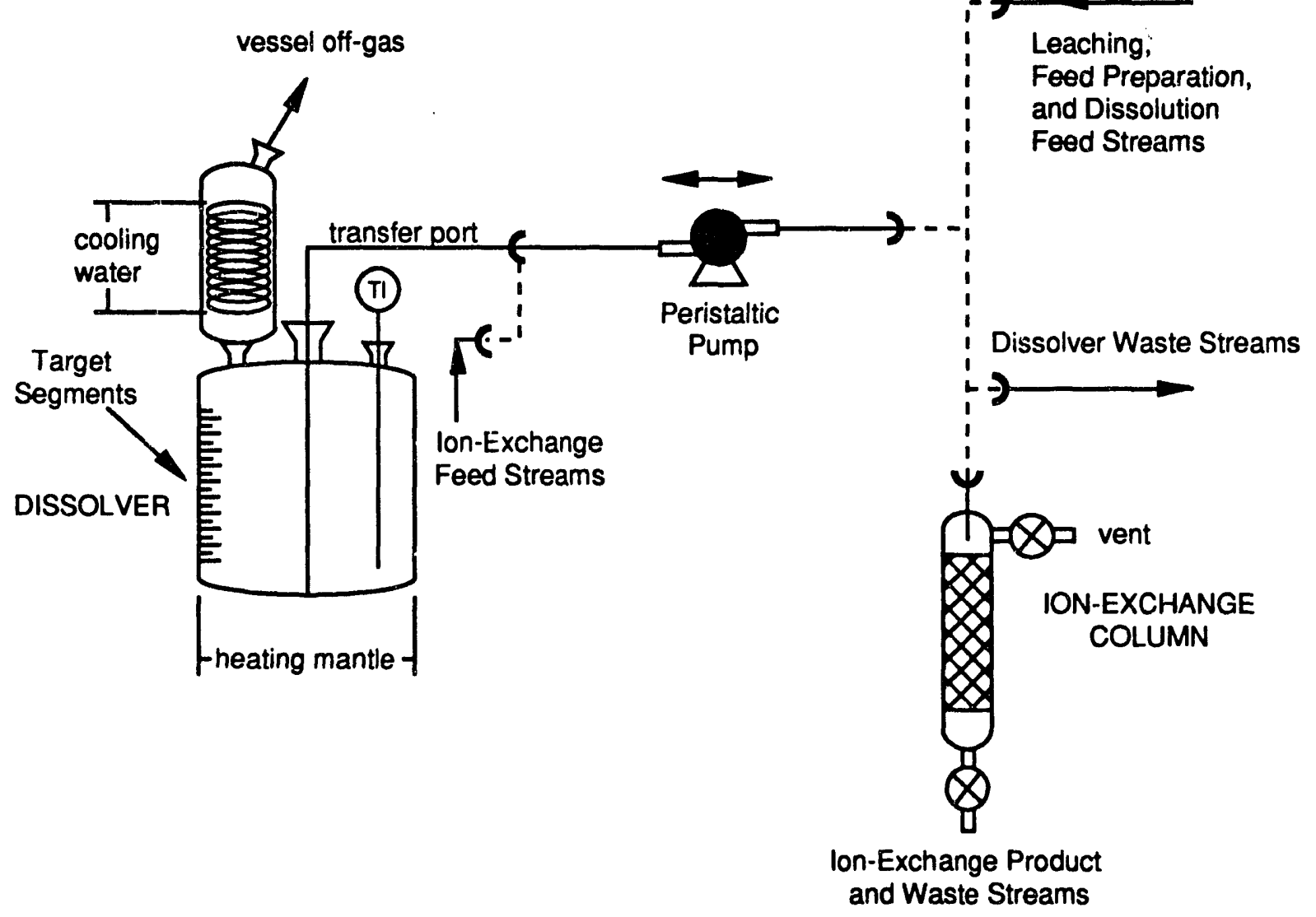

Fig. 4. Equipment diagram for in-cell processing.

Before purification of nickel can proceed, a nitrate-to-chloride conversion step must be carried out. Nitrate is removed by first distilling off as much $\mathrm{HNO}_{3}$ as possible and then destroying the remainder by boiling in the presence of excess $\mathrm{HCl}$. After adjustment to a high

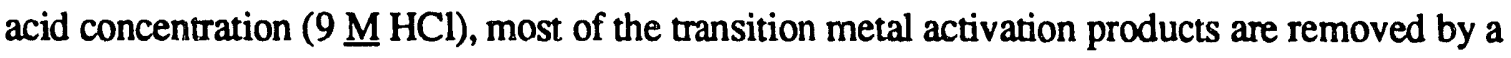
simple "pour-through" anion-exchange column. The anion-exchange product is adjusted to a low acid concentration by boildown and dilution in preparation for ${ }^{46} \mathrm{Sc}$ removal by cation exchange. The penetrating radiation level associaied with the cation-exchange product is low enough to permit the final purification, adjustment, and analysis of the nickel solution to be done in a shielded glove box. Chromium-51 removal is accomplished by extraction of a $1 \underline{\mathrm{M}}$ $\mathrm{HCl}$ product solution with $0.1 \mathrm{M}$ TOPO (trioctylphosphine oxide) in cyclohexane. The final product analysis consists of (a) obtaining accurate weights and volumes on the product 
fraction(s), (b) determining the total nickel concentration by absorption spectrophotometry, and (c) determining the ${ }^{63} \mathrm{Ni}$ content by both scintillation counting $[12,13]$ and mass spectrometry.

\section{DESCRIPTION OF INDIVIDUAL OPERATIONS}

\subsection{TARGET HANDLING AND SECTIONING}

Upon completion of the irradiation cycle, both nickel targets were placed in the HFIR pool (Building 7910) for a cooling period of 2 weeks to allow the substantial shortlived activity (primarily ${ }^{24} \mathrm{Na}$ ) to decay. The transfer of targets from HFIR to REDC was carried out in the same way that curium targets are handled: the LRL-25T cask was used in conjunction with standard REDC procedures. Safe-handling tubes were used to keep the targets clean and undamaged during their handling and transport in the REDC cell bank. Before the targets were sectioned, the outer hex-can was removed by slitting the outer concentric tube along its length. A horizontal jig is installed for this purpose in cubicle 1 and was used according to standard REDC practices to remove the hex-can. The remaining target-rod portions were transferred to cubicle 2 for sectioning (i.e., handsawing) of the active region into two 6-in. segments, as defined by the indexing grooves of a custom jig (Appendix A). The two central six-inch segments for each target were placed in a clean, stoppered, plastic graduate for transfer to cubicle 5 for the remainder of the in-cell processing steps. Throughout all of these target handling procedures, care was taken to minimize cross-contamination by using clean tools and surfaces.

\subsection{TARGET LEACHES AND DISSOLUTIONS}

\subsubsection{Aluminum Removal}

The purpose of preliminary surface leaches is to remove any extraneous activity which may have been deposited on the target surface during irradiation or target handling. Upon transfer to cubicle 5 , the target segments were introduced into clean plastic graduates and subjected to sequential ultrasonic leaches (5-10 min each) with (a) ethanol, (b) $0.5 \underline{\mathrm{M} \mathrm{HCl}}$, and (c) $0.1 \underline{\mathrm{M} \mathrm{HCl}}$. The leach results are summarized in Appendix B and show substantial removal of surface contamination ( $\mathrm{Hf}, \mathrm{W}$, and alpha levels) in addition to the activation $\left({ }^{46} \mathrm{Sc},{ }^{51} \mathrm{Cr},{ }^{54} \mathrm{Mn},{ }^{58,60} \mathrm{Co},{ }^{59} \mathrm{Fe},{ }^{65} \mathrm{Zn}\right)$ associated with the dissolution of a small amount of surface aluminum. 
The removal of the aluminum jacket from fuel [11] and targets [14] by dissolution in caustic is a well-established process and has been conducted as the first step in recovery of transuranium elements from HFIR targets for more than 20 years. ${ }^{*}$ In the case of the ${ }^{63} \mathrm{Ni}$ targets, the goal was to use much smaller and simpler equipment than that used for the standard dissolution of the entire 3-ft-long curium targets. Martens [11] conducted a careful study of the dissolution of aluminum in $\mathrm{NaOH} / \mathrm{NaNO}_{3}$ solutions and found that three dissolution reactions occur simultaneously:

$$
\begin{aligned}
& 2 \mathrm{Al}+2 \mathrm{NaOH}+2 \mathrm{H}_{2} \mathrm{O} \rightarrow 2 \mathrm{NaAlO}_{2}+3 \mathrm{H}_{2} \uparrow \\
& 2 \mathrm{Al}+2 \mathrm{NaOH}+3 \mathrm{NaNO}_{3} \rightarrow 2 \mathrm{NaAlO}_{2}+\mathrm{NaNO}_{2}+\mathrm{H}_{2} \mathrm{O} \\
& 8 \mathrm{Al}+5 \mathrm{NaOH}+3 \mathrm{NaNO}_{3}+2 \mathrm{H}_{2} \mathrm{O} \rightarrow 8 \mathrm{NaAlO}_{2}+3 \mathrm{NH}_{3} \uparrow
\end{aligned}
$$

Reaction (1) occurs at low $\mathrm{NaNO}_{3}$ concentrations ( $<2 \mathrm{wt} \%$ ), whereas reactions (2) and (3) dominate at high $\mathrm{NaNO}_{3}$ concentrations ( $>10 \mathrm{wt} \%$ ). An excess of $\mathrm{NaNO}_{3}$ serves to suppress hydrogen generation, and an excess of caustic acts to maintain $\mathrm{NaAlO}_{2}$ in solution. Since, for batch reactors, the stoichiometry changes continuously as $\mathrm{NaNO}_{3}$ is consumed, the average dissolution stoichiometry should be estimated by integrating along the reaction path curves given by Martens. For the design basis used in this work (Appendix $C$ ), the stoichiometry is approximately as follows:

$$
\begin{gathered}
\mathrm{Al}+0.67 \mathrm{NaOH}+0.5 \mathrm{NaNO}_{3}+0.18 \mathrm{H}_{2} \mathrm{O} \\
\rightarrow \mathrm{NaAlO}_{2}+0.055 \mathrm{NaNO}_{2}+0.015 \mathrm{H}_{2} \uparrow+0.33 \mathrm{NH}_{3} \uparrow
\end{gathered}
$$

The equipment used for aluminum dissolution is quite simple and is schematically illustrated in Fig. 4. The one-piece round-bottom reaction flask $(1 \mathrm{~L})$ has provisions for (a) heating by a variac controlled mantle, (b) operation with either a reflux or concentrating condenser, and (c) introduction or removal of fluids using a reversible peristaltic pump. We found that it was not necessary to filter the dissolver effluent if a magnetic stirring bar was added to retain the nickel fines in the reaction vessel. This simplified operation considerably, because the warm caustic and dissolver sludge invariably plugged the in-line

\footnotetext{
* Because the components of the target are hydrostatically swaged together to provide intimate contact for effective heat-transfer, a mechanical disassembly of the nickel from the aluminum is not easily accomplished.
} 
filters that were initially tested. The contents of the vessel could be stirred by sweeping an external magnet over the dissolver surface. This same vessel and associated equipment were used for all of the hot-cell operations. The caustic is metered (stepwise addition) to the dissolver as a limiting reactant in order to avoid the excessive reaction rates associated with a runaway exothermic dissolution.

\subsubsection{Nickel Dissolution}

Prior to the dissolution of the nickel pellets, a series of rinses is used to flush out the heel from the aluminum dissolution and to clean the pellets and glassware surfaces of other undesirable activation or contamination. The rinses progress from dilute caustic to dilute $\mathrm{HCl}^{*}$ in order to ensure removal of as much extraneous activity as possible. The initial $1 \underline{\mathrm{M} \mathrm{NaOH}}$ rinse serves to maintain any residual $\mathrm{NaAlO}_{2}$ in solution and helps to disperse, dissolve, and remove any other species stable in basic media. The distribution of isotopes in the caustic rinse (Appendix $D$ ) is quite similar to that seen in the dissolved aluminum, except for the prominence of ${ }^{124} \mathrm{Sb}$ and the absence of ${ }^{46} \mathrm{Sc}$ and ${ }^{181} \mathrm{Hf}$.

Following the caustic rinse, water is added to the dissolver, refluxed for $15 \mathrm{~min}$, and removed. The acid rinse sequences were quite different for the two targets. During the processing of the first target, we tried to determine how much leaching of the pellet surface was appropriate. The fact that we really did not have good activation estimates at the time made it difficult to sort out the activity associated with the dissolver heel and that characteristic of the pellets. Five dilute $\mathrm{HCl}$ leaches were conducted on the first target:

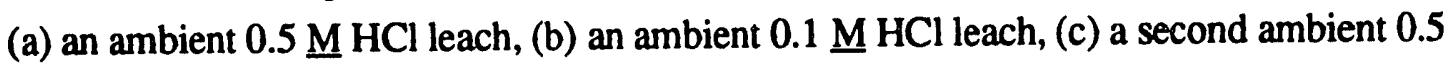
$\underline{\mathrm{M} \mathrm{HCl}}$ leach, (d) a second ambient $0.1 \underline{\mathrm{M}} \mathrm{HCl}$ leach, and finally (e) a $0.2 \underline{\mathrm{M} \mathrm{HCl}}$ leach at reflux (Appendix D). The leach at reflux was by far the most effective; however, it was also apparent from the green tinge of the leachate that some nickel had also been dissolved in the process. Subsequent analysis by scintillation counting put the amount of leached nickel at $0.465 \mathrm{~g}\left(5.43 \mathrm{Ci}^{63} \mathrm{Ni}\right)$. The processing of the second target was simplified by using just two acid rinses: (a) a $0.1 \underline{\mathrm{M}} \mathrm{HCl}$ rinse at reflux and (b) a final $0.5 \mathrm{M} \mathrm{HCl}$ rinse. By halving the concentration of $\mathrm{HCl}$ to $0.1 \mathrm{M}$ during reflux, only a very small amount of nickel $\left(0.1 \mathrm{~g} \mathrm{Ni}, 1.08 \mathrm{Ci}^{63} \mathrm{Ni}\right.$ ) was removed with the leachate (Appendix D).

Some overall evaluation of the effectiveness of the target and pellet leaches is also in order. The basis for this judgment should be the significance of the removals achieved with

\footnotetext{
${ }^{*} \mathrm{HCl}$ is used because it readily dissolves most metals, except nickel.
} 
respect to the product specifications and the separations which would have been achieved by the subsequent operations. This sort of overview requires a consideration of the entire sequence of processing steps and will be dealt with in the Discussion section. In addirion to the gamma scans conducted on the leachates, gross-alpha measurements were also made on the target A leachates and are documented in Appendix D. It is more difficult to evaluate the effectiveness of leaches for removing alpha activity because the product specification is very stringent (Table 1) and our ability to measure low levels of alpha activity is limited by the inevitable cross-contamination which occurs during sampling and handling.

While a chloride solution of nickel is the desired feed for anion exchange, it was found that direct dissolution of nickel pellets in $\mathrm{HCl}$ was impractically slow. Dissolution in nitric acid is much faster and more straightforward. However the stoichiometry is not definite because (a) both $\mathrm{NO}$ and $\mathrm{NO}_{2}$ can be evolved, (b) $\mathrm{NO}$ can be oxidized to $\mathrm{NO}_{2}$, and (c) some recycle of $\mathrm{NO}_{2}$ back as $\mathrm{HNO}_{3}$ can occur. The stoichiometry can be generalized as follows:

$$
\mathrm{Ni}+\underline{\mathrm{a}} \mathrm{HNO}_{3} \rightarrow \mathrm{Ni}\left(\mathrm{NO}_{3}\right)_{2}+\underline{\mathrm{b}} \mathrm{H}_{2} \mathrm{O}+\mathrm{c} \mathrm{NO}_{\mathrm{x}}
$$

with the following coefficients satisfying both the atom balance and redox requirements:

\begin{tabular}{cccc}
$\mathbf{x}$ & $\mathbf{a}$ & $\underline{b}$ & $\mathbf{c}$ \\
\hline 1 & $8 / 3$ & $4 / 3$ & $2 / 3$ \\
2 & 4 & 2 & 2
\end{tabular}

With no recycle of $\mathrm{NO}_{2}$ the maximum consumption $(\mathrm{x}=2)$ is 4 moles of $\mathrm{HNO}_{3}$ per mole of nickel, while the minimum consumption ( $x=1$ or 2 ) of 2 moles of $\mathrm{HNO}_{3}$ per mole of nickel occurs for complete oxidation of $\mathrm{NO}$ to $\mathrm{NO}_{2}$ and $100 \%$ recycle of $\mathrm{NO}_{2}$ as acid. Rough estimates from cold tests put the acid consumption at about 2.5 moles of $\mathrm{HNO}_{3}$ per mole of nickel. A gross excess of $\mathrm{HNO}_{3}$ is not desirable because it must be removed or destroyed in subsequent steps. A practical compromise is to use about $100 \%$ excess acid ( $500 \mathrm{~mL}$ of $4.5 \underline{\mathrm{M} \mathrm{HNO}} \mathrm{HN}_{3}$ ), which provides for dissolution of the pellets (under reflux) at a reasonably rapid rate. To this dissolving acid, a small amount of cobalt chloride (10 $\mathrm{mg}$ of cobalt) was added to act as a holdback carrier during the subsequent anion-exchange step. 


\subsection{NICKEL PURIFICATION}

\subsubsection{Anion-Exchange Removal of Transition Metals}

The dissolved nickel must be converted from a nitrate to a chloride solution and adjusted to the target $9 \underline{\mathrm{M} \mathrm{HCl}}$ concentration prior to anion exchange. After dissolution of the pellets, as much nitric acid as possible was removed by boiling down the product solution to near dryness. The remaining solids and azeotropic liquid $\left(15.4 \underline{\mathrm{M}} \mathrm{HNO}_{3}\right.$, $122^{\circ} \mathrm{C}$ ) still constitute a considerable nitrate inventory which must be destroyed by digestion with concentrated $\mathrm{HCl}(12 \underline{\mathrm{M} \mathrm{HCl}}, 500 \mathrm{~mL})$. This is carried out under reflux until no evidence of further reaction (i.e., $\mathrm{NO}_{\mathrm{x}}$ fumes, gas evolution) is apparent. Finally, the solution is boiled down to the azeotrope $\left(\sim 6 \underline{\mathrm{M} \mathrm{HCl}}, 110^{\circ} \mathrm{C}\right)$ and then adjusted to $9 \underline{\mathrm{M} \mathrm{HCl}}$ by addition of the appropriate amount of concentrated $\mathrm{HCl}$. While it is not critical that the acid concentration be exactly $9 \underline{\mathrm{M}}$ (8.5-10 $\underline{\mathrm{M}}$ is adequate), an improper acid concentration is one of the few parameters which could impair the anion-exchange separation; therefore, a titration was performed on a small sample. The initial acid adjustments were confirmed as acceptable by the titration, and no secondary additions were necessary. Gamma scans on the samples used for titration provided the inventory of radiochemical contaminants listed in Table 2.

The rationale for selecting anion exchange as the central purification operation was given in the Introduction. Before describing the operational details, some discussion of the basis for this separation is in order. Kraus and Nelson's well-known family of adsorption curves (Fig. 1) illustrates that virtually any transition metal can be isolated by selecting the appropriate $\mathrm{HCl}$ concentration during the loading and elution of anion resin $[8,9]$. This technique is especially well suited to nickel purification because all of the transition metals except nickel are sorbed onto anion resin to some degree. ${ }^{*}$ The specificity of anion resin in completely excluding only nickel from its ion-exchange sites is in sharp contrast with the more gradual and predictable sorption behavior typical of conventional ion-exchange operations. This qualitative difference is due to the interesting chemistry of the metalchloride complexes in aqueous solution. Most of the elements of the first transition series form both octahedral complexes with water $\left(\cdot 6 \mathrm{H}_{2} \mathrm{O}\right)$ and tetrahedral chloride complexes

\footnotetext{
${ }^{*} \mathrm{Cr}(\mathrm{III})$ and Ti(III) exhibit only the slightest sorption.
} 
$\left({ }^{4} \mathrm{Cl}^{-}\right)$. Consider the reaction which represents the transition of the divalent metal, $\mathrm{M}^{2+}$, from octahedral (i.e., hexaquo) to tetrahedral coordination:

$$
\left[\mathrm{M}\left(\mathrm{H}_{2} \mathrm{O}\right)_{6}\right]^{2+}+4 \mathrm{Cl}^{-} \rightarrow\left[\mathrm{MCl}_{4}\right]^{2-}+6 \mathrm{H}_{2} \mathrm{O}
$$

For a closely related sequence of metals, the contributions to the energy of this transition" should follow some regular pattern, except for the contribution that derives from the interaction of the outer d-electron orbitals and the ligand coordination geometry. Ligand field theory studies of this interaction have shown that a ligand field stabilization energy (LFSE) exists which acts to promote coordinated cemplexation, as compared with "unstructured" complexation [15]. The fact that $\mathrm{Ni}(\mathrm{II})$ is not adsorbed and $\mathrm{Cr}$ (III) is only sparingly adsorbed onto anion resin is due to the uncommonly large LFSE difference (Table 3) that acts to stabilize the hexaquo complex in preference to the anionic chloride complex. Note that other factors, such as ionic radius and oxidation state, also influence the strength of complexation and subsequent sorption. $\mathrm{Mn}$ (II) and $\mathrm{Fe}$ (III) are isoelectronic (both $d^{5}$ ) and yet show marked differences in adsorption behavior [9]. These differences can be attributed, in part, to the greater complexing tendency of the higher-oxidation-state metals. The surprising ability of $\mathrm{Pd}(\mathrm{II})$, the second transition series analog to $\mathrm{Ni}(\mathrm{II})$, to sorb on anion resin is due to the inability of the platinum metals to form the hexaquo complexes which compete with the chloride complexes. Finally, we note that, since the unusual stability of the hexaquo complex of nickel precludes speciation, a measurement of the visible absorption spectrum of the product solution provides a rapid and accurate nickel assay, as described in Sect. 5.1.

In practice, anion-exchange purification is quite straightforward and consists of the typical sequential steps of conditioning, loading, "washing" (i.e., displacement of nickel), and stripping. The loading acid concentration of $9 \underline{\mathrm{M} \mathrm{HCl}}$ was chosen to maximize the distribution coefficient $\left(D_{\mathrm{v}}\right)$ for cobalt, ${ }^{\dagger}$ which was presumed to be the limiting isotope from a radiochemical separations standpoint. Since cobalt is not strongly sorbed even in $9 \underline{\mathrm{M} \mathrm{HCl}}\left(\mathrm{D}_{\mathrm{v}} \sim 70\right)$, an oversized column ${ }^{\ddagger}($ Dowex $1-\mathrm{X} 8,100-200$ mesh, $2 \mathrm{~cm} \mathrm{ID} \times 20 \mathrm{~cm}$

\footnotetext{
*For example, the metal-ligand bond energy, hydration energies, and ligand polarization energies.

${ }^{\dagger}$ Radiocobalt is inevitably produced during irradiation of nickel because of the trace cobalt associated with even the purest nickel. Nickel $(n, p)$ reactions provide a secondary pathway.

"Based upon the 10.mg cobalt "holdback" carrier addition and the feed impurities, less than 10 meq of Co(II) is present. No other carriers were used.
} 
Table 3. Ligand field stabilization energies

\begin{tabular}{ccccl}
\hline \multirow{2}{*}{$\begin{array}{c}\text { Number of } \\
\text { d electrons }\end{array}$} & \multicolumn{2}{c}{ Stabilization energies (in $\Delta_{0}$ units) } & \multirow{2}{*}{$\begin{array}{c}\text { Common ions of first } \\
\text { transition series }\end{array}$} \\
\cline { 2 - 4 } & Octahedral & Tetrahedral & Difference & \\
\hline 1,6 & 0.4 & 0.3 & 0.1 & $\mathrm{Ti}(\mathrm{III}), \mathrm{V}(\mathrm{IV}), \mathrm{Fe}$ (II) \\
2,7 & 0.8 & 0.6 & 0.2 & $\mathrm{Co}(\mathrm{II})$ \\
3,8 & 1.2 & 0.4 & 0.8 & $\mathrm{Cr}(\mathrm{III}), \mathrm{Ni}(\mathrm{II})$ \\
4,9 & 0.6 & 0.2 & 0.4 & $\mathrm{Cu}$ (II) \\
$0,5,10$ & 0.0 & 0.0 & 0.0 & $\mathrm{Mn}$ (II), $\mathrm{Fe}(\mathrm{III}), \mathrm{Zn}$ (II) \\
\hline
\end{tabular}

long) was used to ensure that the cobalt band would not bleed into the product fraction. The first step in the anion-exchange separation is to condition for high-acid operation by pumping three bed volumes of $9 \underline{\mathrm{M} \mathrm{HCl}}$ through the column to displace the resident dilute acid used for resin storage. The feed solution $(\sim 300 \mathrm{~mL}, 40 \mathrm{~g} / \mathrm{L} \mathrm{Ni}, 9 \underline{\mathrm{M} \mathrm{HCl}})$ is slowly pumped $(2.5 \mathrm{~mL} / \mathrm{min})$ to the column to ensure the formation of tight adsorption bands. Following loading, the nickel is fully displaced from the column by a $9 \underline{\mathrm{M} \mathrm{HCl}}$ wash $(\sim 150 \mathrm{~mL}$ at $2.5 \mathrm{~mL} / \mathrm{min})$. Recovery and isolation of $\mathrm{Co}, \mathrm{Fe}$, and $\mathrm{Zn}$ were achieved by sequential elution with $3 \underline{\mathrm{M}}, 0.5 \underline{\mathrm{M}}$, and $0.005 \mathrm{M} \mathrm{HCl}(\sim 150 \mathrm{~mL}$ each at $2.5 \mathrm{~mL} / \mathrm{min})$. All of the cuts between fractions we:e made using either the characteristic color of the effluent stream or the in-cell gamma probe as an indicator. Although these rough guides were adequate for our purposes, operations with in-line instrumentation (e.g., spectrophotometry) offer the opportunity for optimized separations and even higher stream purity.

Two separate "cold" tests with natural nickel were performed to assess the performance of the ion-exchange column prior to hot-cell operations. The first test, a ${ }^{60} \mathrm{Co}$ tracer test, was designed to provide an accurate estimate of the cobalt decontamination factor $^{*}$ (DF), while the second test, truly a cold test (i.e., no tracer), had the broader focus of providing an estimate of the likely separation achieved from the host of contaminants present. Both experiments used a nickel feed solution derived from simulated target rods

*The decontamination factor for species $i$ is defined as follows: $D F_{i}=(\text { feed inventory })_{i}$ /product inventory $)_{i}$. 
processed according to the previously described operations (i.e., aluminum dissolution, leaches). The stand-in nickel pellets were no purer than the actual enriched pellets, and the aluminum alloys were of the lot used in the actual target fabrication and accurately reflect the chemical impurities (Appendix $C$ ) likely to be carried over to the anion-exchange step. The tracer experiment yielded a cobalt DF of about $2 \times 10^{5}$, which is certainly more than adequate for the predicted cobalt inventory in the anion-exchange feed. The analytical results from the second cold test (Table 4) are in accord with the predictions of Kraus and Nelson [9]: all of the transition metals except $\mathrm{Ni}, \mathrm{Cr}$, and $\mathrm{Mn}^{*}$ are effectively removed by anion exchange in $9 \underline{\mathrm{M} \mathrm{HCl}}$, while the alkali metals, pretransition metals, and rare earths/actinides pass through the column.

Table 4. Results from second anion-exchange cold test

\begin{tabular}{crrr}
\hline Element $^{a}$ & $\begin{array}{c}\text { Amount in } \\
\text { feed } \\
(\mathrm{mg})\end{array}$ & $\begin{array}{c}\text { Amount in } \\
\text { product } \\
(\mathrm{mg})\end{array}$ & $\mathrm{DF}^{b}$ \\
\hline $\mathrm{Al}$ & 5.10 & 5.20 & 1.0 \\
$\mathrm{~B}$ & 0.48 & 0.52 & 0.9 \\
$\mathrm{Ba}$ & 0.06 & 0.02 & 2.5 \\
$\mathrm{Ca}$ & 0.45 & 0.30 & 1.5 \\
$\mathrm{Co}$ & 19.50 & $<0.02$ & $>975.0$ \\
$\mathrm{Cr}$ & 0.14 & 0.06 & 2.1 \\
$\mathrm{Cu}$ & 3.60 & $<0.03$ & $>128.6$ \\
$\mathrm{Fe}$ & 360.00 & 0.02 & 18000.0 \\
$\mathrm{Mg}$ & 0.13 & 0.11 & 1.2 \\
$\mathrm{Mn}$ & 0.93 & 0.80 & 1.2 \\
$\mathrm{Na}$ & 1.23 & 0.56 & 2.2 \\
$\mathrm{Ni}$ & 13500.00 & 12800.00 & 1.1 \\
$\mathrm{Si}$ & 1.98 & 0.80 & 2.5 \\
$\mathrm{Sn}$ & 0.33 & $<0.20$ & $>1.7$ \\
Total nonnickel mass & 393.9 & 8.1 & 48.4 \\
\hline
\end{tabular}

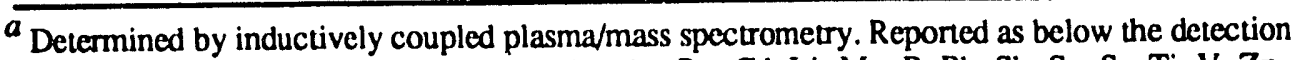
limits in both the feed and product were Ag, As, Be, Cd, Li, Mo, P, Pb, Sb, Se, Sr, Ti, V, Zn, and $\mathrm{Zr}$.

$b^{b}$ Decontamination factor.

* $\mathrm{A} 12 \mathrm{M} \mathrm{HCl}$ loading acid concentration could have been used to retain manganese $\left(\mathrm{D}_{v} \sim 5\right)$. 
While the hot-cell operations were carried out as previously described and performed (Tables 5 and 6 ) as predicted by the cold tests, some additional description of the operations is required. The fact that the anion-exchange feed for both targets contained far more ${ }^{51} \mathrm{Cr}$ and ${ }^{46} \mathrm{Sc}$ than originally anticipated posed a significant radiation exposure hazard for the final glove box finishing steps. For the processing of target $\mathrm{A}$, the first cycle of anion exchange was carried out precisely as described earlier and resulted in a product dominated by ${ }^{46} \mathrm{Sc}$ and ${ }^{51} \mathrm{Cr}$ activity. To effect some degree of chromium removal, the product solution was treated to oxidize the chromium to chromate and fed (at low acid) once more to the anion-exchange column. A modification of the recipe suggested by Burgus [16] was used to oxidize the chromium after the product solution had been adjusted to less than $0.2 \underline{\mathrm{M} \mathrm{HCl}}$ by boiling down and redilution. A reduction of the ${ }^{51} \mathrm{Cr}$ activity in the product by a factor of five is inferred from the subsequent cation-exchange results (Table 5). For the second target, the chromium oxidation step was attempted before the adjustment to high acid, which precedes anion exchange. Apparently, the subsequent

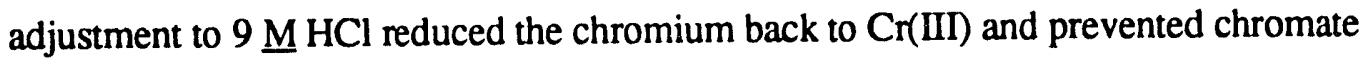
removal during anion exchange (Table 6).

Table 5. Results for the purification of nickel (target A)

\begin{tabular}{|c|c|c|c|c|c|c|}
\hline \multirow[t]{2}{*}{ Isotope } & \multirow{2}{*}{$\begin{array}{l}\text { Activity in } \\
\text { feed nickel } \\
\text { (mCi) }\end{array}$} & \multirow{2}{*}{$\begin{array}{l}\text { Anion- } \\
\text { exchange } \\
\mathrm{DF}^{a}\end{array}$} & \multirow{2}{*}{$\begin{array}{c}\text { Cation- } \\
\text { exchange } \\
\mathrm{DF}^{a}\end{array}$} & \multicolumn{2}{|c|}{$\begin{array}{c}\text { TOPO-extraction } \\
\text { DF }^{a}\end{array}$} & \multirow{2}{*}{$\begin{array}{l}\text { Final } \\
\text { product } \\
(\mathrm{mCi})\end{array}$} \\
\hline & & & & 1st cycle & 2nd cycle & \\
\hline${ }^{46} \mathrm{Sc}$ & 25 & $\sim 1$ & Complete & - & - & - \\
\hline${ }^{51} \mathrm{Cr}$ & 675 & $\sim 1,4.7$ & $\sim 1$ & 11 & 5.5 & 2.0 \\
\hline${ }^{54} \mathrm{Mn}$ & 0.2 & $\sim 1$ & $\sim 1$ & $\sim 1$ & $\sim 1$ & 0.15 \\
\hline${ }^{58} \mathrm{Co}$ & 89 & $3 \times 10^{4}$ & $\sim 1$ & $\sim 1$ & $\sim 1$ & 0.003 \\
\hline${ }^{59} \mathrm{Fe}$ & 57 & 2000 & $\sim 1$ & Complete & - & - \\
\hline${ }^{60} \mathrm{Co}$ & 125 & $3 \times 10^{4}$ & $\sim 1$ & $\sim 1$ & $\sim 1$ & 0.004 \\
\hline${ }^{65} \mathrm{Zn}$ & 7 & Complete & - & - & - & - \\
\hline${ }^{134} \mathrm{Cs}$ & 0.2 & $\sim 1$ & $\sim 1$ & $\sim 1$ & $\sim 1$ & 0.2 \\
\hline${ }^{136} \mathrm{Cs}$ & 0.1 & $\sim 1$ & $\sim 1$ & $\sim 1$ & $\sim 1$ & 0.06 \\
\hline${ }^{137} \mathrm{Cs}$ & 0.005 & $\sim 1$ & $\sim 1$ & $\sim 1$ & $\sim 1$ & 0.004 \\
\hline
\end{tabular}

\footnotetext{
$a_{\text {Decontamination factor. }}$
} 
Table 6. Results for the purification of nickel (target B)

\begin{tabular}{cccccc}
\hline Isotope & $\begin{array}{c}\text { Activity in } \\
\text { feed nickel } \\
(\mathrm{mCi})\end{array}$ & $\begin{array}{c}\text { Anion- } \\
\text { exchange } \\
\mathrm{DF}^{a}\end{array}$ & $\begin{array}{c}\text { Cation- } \\
\text { exchange } \\
\mathrm{DF}^{a}\end{array}$ & $\begin{array}{c}\text { TOPO- } \\
\text { extraction } \\
\mathrm{DF}^{a}\end{array}$ & $\begin{array}{c}\text { Final } \\
\text { product } \\
\text { (mCi) }\end{array}$ \\
\hline${ }^{46} \mathrm{Sc}$ & 0.5 & $\sim 1$ & Complete & - & - \\
${ }^{51} \mathrm{Cr}$ & 5 & 1.2 & 1.3 & 154 & 0.02 \\
${ }^{54} \mathrm{Mn}$ & 0.07 & $\sim 1$ & $\sim 1$ & $\sim 1$ & 0.06 \\
${ }^{58} \mathrm{Co}$ & 18 & $1.6 \times 10^{4}$ & $\sim 1$ & $\sim 1$ & $0.03^{b}$ \\
${ }^{59} \mathrm{Fe}$ & 15 & 2000 & $\sim 1$ & Complete & - \\
${ }^{60} \mathrm{Co}$ & 24 & $1.6 \times 10^{4}$ & $\sim 1$ & $\sim 1$ & $0.046^{b}$ \\
${ }^{65} \mathrm{Zn}$ & 17 & $\mathrm{Complete}$ & - & - & - \\
${ }^{110 \mathrm{~m}} \mathrm{Ag}$ & 0.1 & $\sim 1$ & 2 & 3 & 0.02 \\
${ }^{124} \mathrm{Sb}$ & 1.8 & 60 & $\sim 1$ & $\sim 1$ & 0.03 \\
\hline${ }^{a}$ Decontamination factor. & & & & \\
${ }^{b}$ Final cobalt levels are elevated due to minor cross-contamination after anion exchange.
\end{tabular}

\subsubsection{Cation-Exchange Removal of Scandium}

The feed preparation for cation exchange is simply a conversion of the $9 \underline{\mathrm{M} \mathrm{HCl}}$ anion-exchange product to a dilute-acid solution $(<0.5 \underline{\mathrm{M} \mathrm{HCl}})$ by boiling down and dilution. This is accomplished using the same equipment described earlier and in the same fashion that the anion-exchange feed was adjusted to high acid. The primary purpose of the cation-exchange step is to remove the ${ }^{46} \mathrm{Sc}$ activity from the product solution. A small "pour-through" column (i.e., the nickel is not quantitatively loaded) is adequate to retain the trivalent scandium and any actinide contamination, while the displaced and eluted nickel is collected as product. The same basic set of hot-cell equipment is used (Fig. 4), with the exception of a new cation-exchange column $(2 \mathrm{~cm} \mathrm{ID} \times 20 \mathrm{~cm}$ long, Dowex $50 \mathrm{~W}-\mathrm{X} 8,200$ 400 mesh). Because only retention of $\mathrm{Sc}(\mathrm{III})$ is required, column operation is very straightforward: the monovalent, divalent, and $\mathrm{Cr}(\mathrm{III})$ ions are displaced from the column during the loading ( $400 \mathrm{~mL}, 30 \mathrm{~g} / \mathrm{L} \mathrm{Ni}$ in $0.05 \underline{\mathrm{M} \mathrm{HCl}})$, washing $(100 \mathrm{~mL} 0.1 \underline{\mathrm{M} \mathrm{HCl}})$, and elution $(\sim 200 \mathrm{~mL} 2 \mathrm{M} \mathrm{HCl})$ of the nickel - leaving only scandium and the actinides to

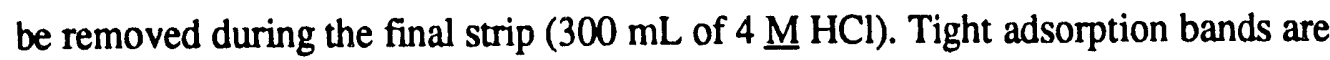


maintained by operating at a low flow rate $(2.5 \mathrm{~mL} / \mathrm{min})$, and the product cuts are readily made based upon the color of the effluent from the column. No ${ }^{46} \mathrm{Sc}$ was detected in either cation-exchange product, and ${ }^{51} \mathrm{Cr}$ was the dominant activity remaining (Tables 5 and 6).

\subsubsection{Chromium Removal by TOPO Extraction}

Most techniques for the selective removal of chromium from aqueous solutions require the oxidation of the stable $\mathrm{Cr}$ (III) to the strongly oxidizing $\mathrm{Cr}$ (VI). In this higher oxidation state, chromium ${ }^{*}$ exists as an anion at low acid concentrations and is readily separated from other metal cations. The oxidation must be carried out at a low acid concentration $([\mathrm{HCl}]<0.1 \underline{\mathrm{M}})$ so that chromium, rather than $\mathrm{Cl}^{-}$, is attacked by the oxidant $\left(\mathrm{NaBrO}_{3}\right)$ and so that the chromate formed is not reduced back to $\mathrm{Cr}$ (III) by additional oxidation of the chloride [16]. After oxidation, the acidity is raised to the optimal value for removal of chromium by extraction with TOPO $\left(\sim 1 \underline{\mathrm{M} \mathrm{HCl}}, \mathrm{D}_{\mathrm{v}}=100\right)$. The feed preparation step is more critical to the success of this separation than are the details of the extraction procedure. Effective chromium removal by TOPO extraction is achieved only if (a) the oxidation is carried out in very dilute $\mathrm{HCl}$, (b) the oxidation is carried to completion (boil oxidation mixture for at least $15 \mathrm{~min}$ ) with no reduction back to $\mathrm{Cr}$ (III), and (c) the extractant is presaturated with $1 \underline{\mathrm{M} \mathrm{HCl}}$ and a small amount of $\mathrm{NaBrO}_{3}$ oxidant.

In a typical extraction, equal $250-\mathrm{mL}$ phase volumes of aqueous nickel and TOPO extractant ( $0.1 \mathrm{M}$ TOPO in cyclohexane) are vigorously stirred in a 1-L separatory funnel for $15 \mathrm{~min}$. The first extraction is followed immediately with a second contacting with fresh extractant. For target A, two cycles of oxidation/extraction (two contactings per cycle) were required to remove the large inventory of ${ }^{51} \mathrm{Cr}$. The separation factor for each extraction cycle was only about 10 (Table 5), which is somewhat disappointing since a literature value $[17,18]$ of about 100 is quoted for the chromium distribution coefficient under these conditions. For the second target, special care was taken to ensure complete oxidation of the chromium, and the extra precaution of pretreating the solvent with a small amount $(\sim 1 \mathrm{mmol})$ of $\mathrm{NaBrO}_{3}$ oxidant was taken. ${ }^{\dagger}$ A separation factor of 100 was realized in just one contacting, and an overall factor of 154 for the first cycle was achieved after the follow-up contacting (Table 6). The recovery of nickel in the final product was about $95 \%$

\footnotetext{
"Present as $\mathrm{CrO}_{4}{ }^{2-}, \mathrm{HCrO}_{4}^{-}, \mathrm{Cr}_{2} \mathrm{O}_{7}{ }^{2-}$, or $\mathrm{H}_{2} \mathrm{CrO}_{4}$ depending on $\mathrm{pH}$.

${ }^{\dagger}$ To counteract the effect of any reducing sites present in the solvent.
} 
for both targets, with most of the losses occurring during the pellet leaches. The balance of the "losses" were due to sampling, nickel burnout (i.e., transmutation), and uncertainties in the feed assay.

\section{FINAL PRODUCT ASSAY AND ANALYSIS}

\subsection{FINISHED PRODUCT DESCRIPTION}

The product from solvent extraction is boiled down to near dryness and redissolved

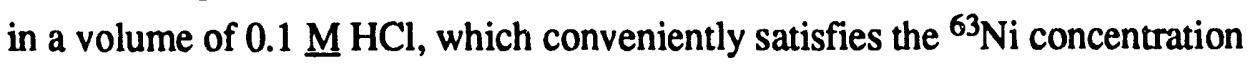
specification (500-2000 $\mathrm{mCi} / \mathrm{mL}$ ). The properties and characteristics of the final packaged products are given in Table 7 . In addition to measurement of the product weight and density, the ${ }^{63} \mathrm{Ni}$ content was determined by both scintillation counting and mass spectrometry. The total nickel present in the product was determined by an absorption spectrophotometry method, which is described in the following section.

\subsection{TOTAL NICKEL DETERMINATION BY ABSORPTION SPECTROPHOTOMETRY}

The inherent stability (p. 13) and distinct green color of the nickel-hexaquo complex suggest that an accurate determination of the total nickel in the product solution can be made using absorption spectrophotometry. Because nickel is present in such large excess with respect to any other absorbing species, the product solution is effectively a one-component system. Therefore, no specific colorimetric developing agents are necessary to isolate the nickel or amplify its absorptivity. Furthermore, since the determination can be made on the actual product solution, an extremely accurate assay should be possible. Another feature which makes absorption spectrophotometry particularly attractive is the presence of two strong and distinct absorption peaks in the nickel spectrum which can be used for independent determinations (Fig. 5).

In multicomponent systems, the absorption at a particular fixed wavelength(s), rather than an absorption maxima, is usually employed to avoid the uncertainty associated with the position of the peak due to the contributions of the individual absorbing species. This puts a premium on both wavelength stability and accuracy, especially in regions where the absorbance slope, $d A / d \lambda$, is large. In our (single-component) case, it is simpler and more accurate to use the absorbance maxima for calibrations and determinations, because at these maxima $d A / d \lambda=0$ and any absorbing contaminants will (proportionately) have the least influence on the concentration estimate. Extensive measurements were performed on a 
Table 7. Physical, chemical, radiochemical, and isotopic description of ${ }^{63} \mathrm{Ni}$ products

\begin{tabular}{|c|c|c|}
\hline Property & Target A product & Target B product \\
\hline Volume (mL) & 115.2 & 98.0 \\
\hline Weight (g) & 135.2 & 114.7 \\
\hline Chemical form & \multicolumn{2}{|c|}{$\mathrm{NiCl}_{2}$ salt dissolved in $0.1 \underline{\mathrm{M} \mathrm{HCl}}$} \\
\hline Nickel concentration & $1.53 \underline{\mathrm{M}}, \sim 95 \mathrm{~g} / \mathrm{L}$ & $1.51 \underline{\mathrm{M}}, \sim 93.8 \mathrm{~g} / \mathrm{L}$ \\
\hline Nickel loaded in target (g) & $\sim 12$ & $\sim 10$ \\
\hline Total nickel recovered $(\mathrm{g})$ & 10.94 & 9.19 \\
\hline $\begin{array}{l}{ }^{63} \mathrm{Ni} \text { specific activity by } \\
\text { scintillation counting }\end{array}$ & $\begin{array}{l}1.08 \mathrm{mCi} / \mathrm{mL} \\
=11.4 \mathrm{Ci} / \mathrm{g}\end{array}$ & $\begin{array}{l}0.946 \mathrm{mCi} / \mathrm{mL} \\
=10.1 \mathrm{Ci} / \mathrm{g}\end{array}$ \\
\hline $\begin{array}{l}\text { Ni specific activity by } \\
\text { mass analysis }\end{array}$ & $11.67 \mathrm{Ci} / \mathrm{g}$ & $10.49 \mathrm{Ci} / \mathrm{g}$ \\
\hline Alpha activity & $<25 \mathrm{nCi}$ & $<23.5 \mathrm{nCi}$ \\
\hline Isotope & \multicolumn{2}{|c|}{ Activity of gamma emitters (mCi) } \\
\hline${ }^{51} \mathrm{Cr}$ & 2.026 & 0.020 \\
\hline${ }^{54} \mathrm{Mn}$ & 0.154 & 0.064 \\
\hline${ }^{58} \mathrm{Co}$ & 0.003 & 0.028 \\
\hline${ }^{60} \mathrm{Co}$ & 0.004 & 0.046 \\
\hline${ }^{110 \mathrm{~m}} \mathrm{Ag}$ & - & 0.016 \\
\hline${ }^{124} \mathrm{Sb}$ & - & 0.028 \\
\hline${ }^{134} \mathrm{Cs}$ & 0.218 & - \\
\hline${ }^{136} \mathrm{Cs}$ & 0.068 & - \\
\hline${ }^{137} \mathrm{Cs}$ & 0.004 & - \\
\hline Total mCi & 2.48 & 0.202 \\
\hline Nickel isotopics & At. \%, target A & At. \%, target B \\
\hline 58 & $2.07 \pm 0.06$ & $1.51 \pm 0.05$ \\
\hline 60 & $1.50 \pm 0.01$ & $1.03 \pm 0.08$ \\
\hline 61 & $0.23 \pm 0.03$ & $0.28 \pm 0.05$ \\
\hline 62 & $69.11 \pm 0.10$ & $73.86 \pm 0.28$ \\
\hline 63 & $20.34 \pm 0.09$ & $18.28 \pm 0.28$ \\
\hline 64 & $6.76 \pm 0.11$ & $5.04 \pm 0.10$ \\
\hline
\end{tabular}




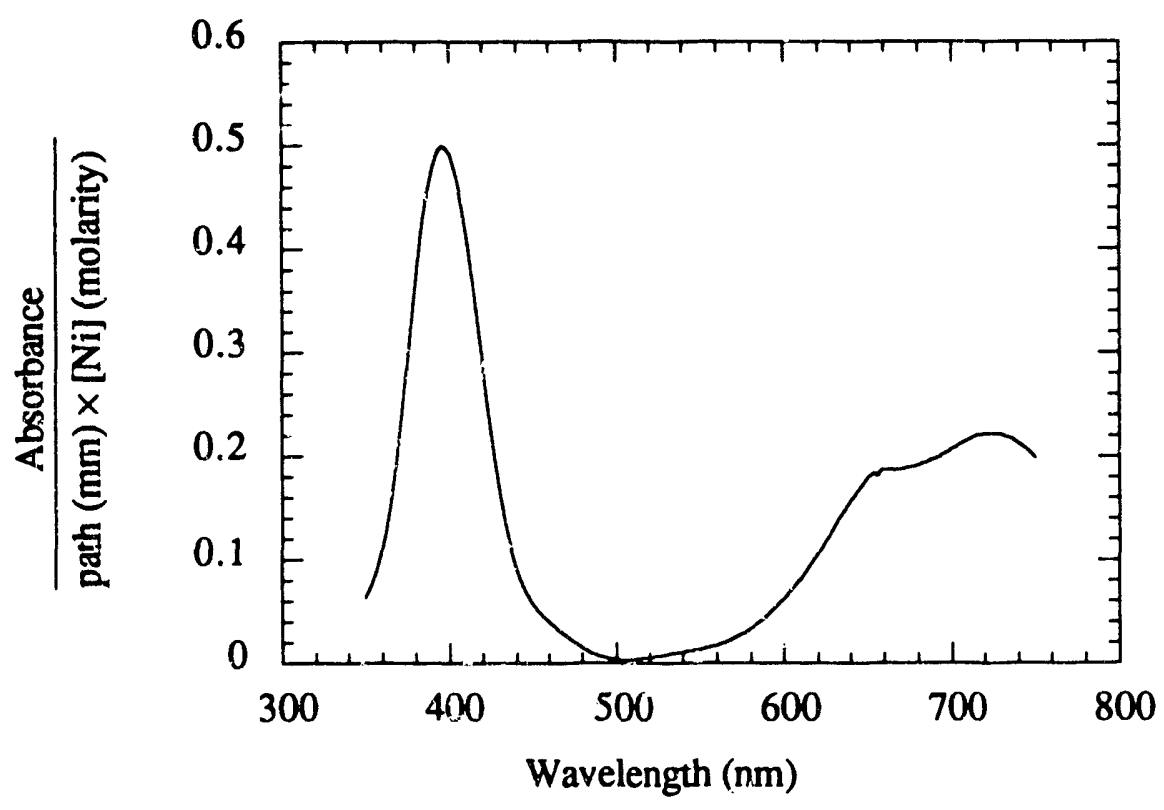

Fig. 5. Typical nickel spectrum in dilute $\mathbf{H C l}$.

series of standard solutions in order to confirm the accuracy of the proposed spectrophotometric method. A concentrated $(\sim 2 \underline{\mathrm{M}} \mathrm{Ni})$ stock solution was made by dissolving $47.59 \mathrm{~g}$ of $\mathrm{NiCl}_{2} \cdot 6 \mathrm{H}_{2} \mathrm{O}$ with $0.1 \mathrm{M} \mathrm{HCl}$. Precise stepped dilutiors of the concentrated stock solution permitted the gravimetric measurements displayed in Table 8 and Fig. 6.

The instrument employed for absor'oance measurements is a modified HewlettPackard HP8452 diode-array spectrophotometer. The unit is controlled by an IBM/ATcompatible computer running data acquisition and analysis software developed at Savannah River Laboratories [19]. Fiber-optic couplings and sample-cell holders are very similar to those described in another Savannah River Laboratories report [20] and are used to isolate the instrumentation from the glove box interior. The product solution is so concentrated that a short parh-length cell (Hellma 110-QS, 2-mm path) must be used to ensure that the measured absorbance falls in the range (0.3-2.0) prescribed for accurate determinations. 
Table 8. $\mathrm{NiCl}_{2}$ solution standards (in $0.1 \mathrm{M} \mathrm{HCl}$ )

\begin{tabular}{ccccc}
\hline $\begin{array}{c}\text { Nominal }[\mathrm{Ni}] \\
(\mathrm{M})\end{array}$ & $\begin{array}{c}\text { Weight of } \\
2 \mathrm{M} \text { stock } \\
\text { solution }(\mathrm{g})\end{array}$ & $\begin{array}{c}\text { Weight of } \\
25-\mathrm{mL} \\
\text { standard }(\mathrm{g})\end{array}$ & $\begin{array}{c}\text { Specific } \\
\text { gravity }\end{array}$ & $\begin{array}{c}\text { Exact }[\mathrm{Ni}] \\
(\mathrm{M})\end{array}$ \\
\hline 0.00 & 0.000 & 25.013 & 1.0005 & 0.0000 \\
0.10 & 1.521 & 25.250 & 1.0100 & 0.099387 \\
0.20 & 3.030 & 25.520 & 1.0208 & 0.19799 \\
0.50 & 7.603 & 26.384 & 1.0554 & 0.49681 \\
1.00 & 15.280 & 27.831 & 1.1132 & 0.99845 \\
1.25 & 19.052 & 28.522 & 1.1409 & 1.2449 \\
1.50 & 22.975 & 29.216 & 1.1686 & 1.5013 \\
1.75 & 26.770 & 29.871 & 1.1948 & 1.7492 \\
2.00 & 30.608 & 30.608 & 1.2243 & 2.0000 \\
\hline
\end{tabular}

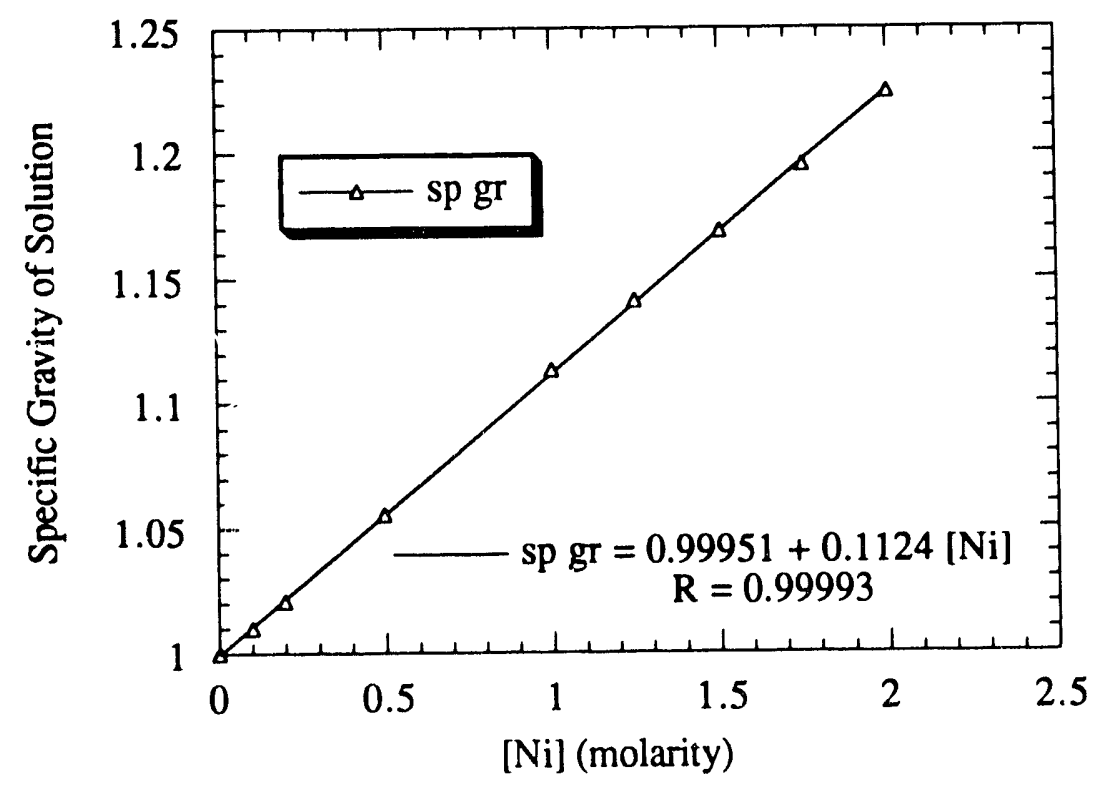

Fig. 6. Specifir gravity of solution standards at $20^{\circ} \mathrm{C}$. 
Since a single-beam spectrometer is employed, a reference spectrum must be acquired just prior to each measurement on nickel-containing solutions. This is most conveniently done by using a pair of cells: one cell dedicated for measurements with reference liquid $(0.1 \underline{\mathrm{M} \mathrm{HCl}})$ and another for use with solution standards or product solution. The ten replicate measurements performed on each nickel solution were characterized by standard deviations less than $0.5 \%$ and typically around $0.1 \%$. This variation (Table 9) in replicate measurements is primarily a reflection of the drift in the light-source intensity during the period between reference measurements. The variation of absorbance with nickel concentration exhibited the typical linear Beer's law behavior (Fig. 7).

Table 9. Absorbance measurements on solution standards

\begin{tabular}{ccc}
\hline Nominal $[\mathrm{Ni}](\mathrm{M})$ & 1st peak absorbance & 2nd peak pbsorbance \\
\hline 0.1 & $0.11518 \pm 0.36 \%$ & $0.059251 \pm 0.45 \%$ \\
0.2 & $0.21493 \pm 0.4 \%$ & $0.098211 \pm 0.8 \%$ \\
0.5 & $0.51655 \pm 0.097 \%$ & $0.22902 \pm 0.15 \%$ \\
1.0 & $1.0283 \pm 0.09 \%$ & $0.45524 \pm 0.12 \%$ \\
1.25 & $1.2727 \pm 0.12 \%$ & $0.56367 \pm 0.012 \%$ \\
1.5 & $1.5314 \pm 0.06 \%$ & $0.67776 \pm 0.034 \%$ \\
1.75 & $1.7726 \pm 0.095 \%$ & $0.79128 \pm 0.078 \%$ \\
2.0 & $2.0225 \pm 0.21 \%$ & $0.92007 \pm 0.097 \%$ \\
\hline
\end{tabular}




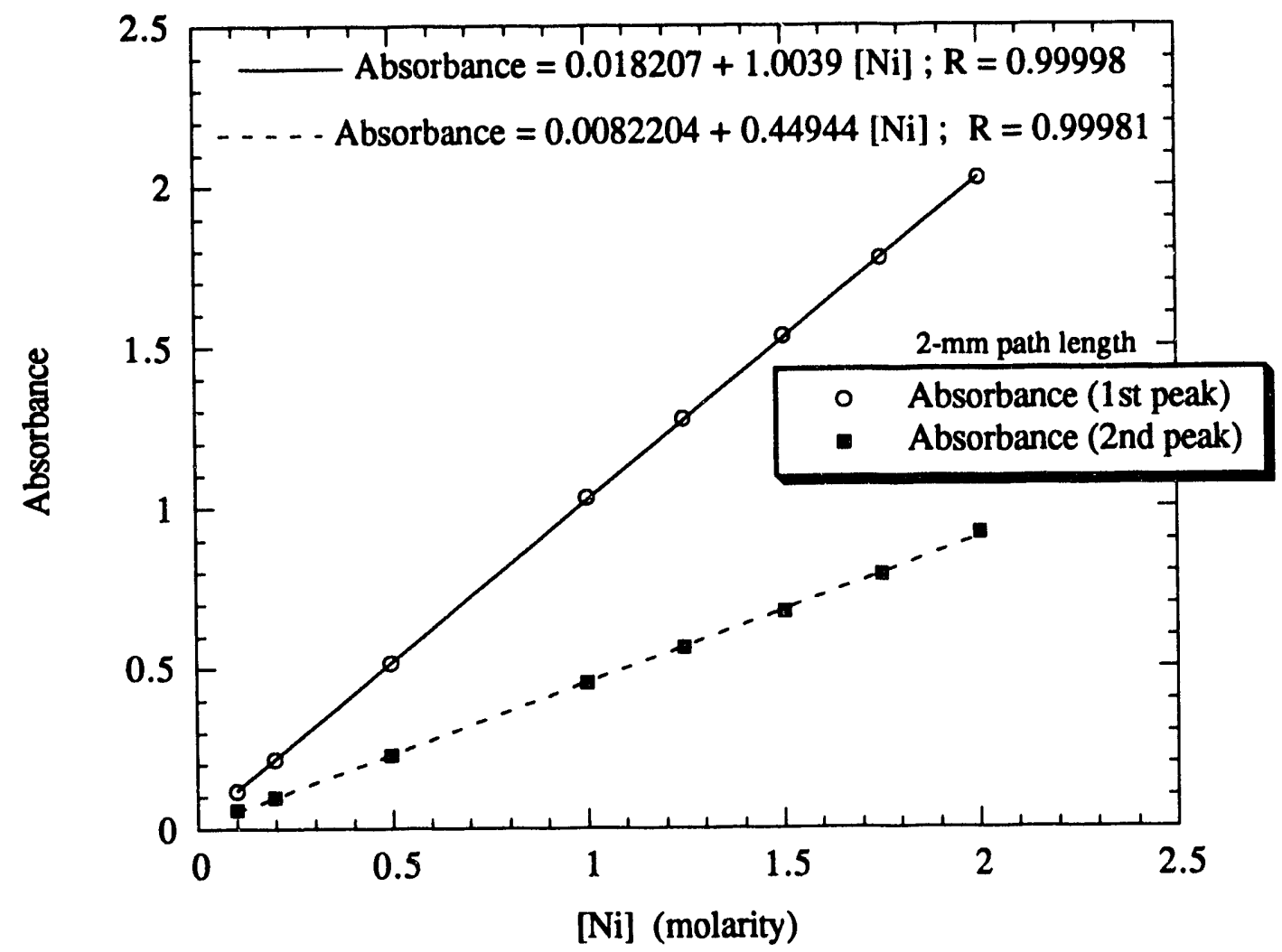

Fig. 7. Beer's law plot of solution standards.

Rather than rely solely on the absorbance vs. nickel concentration calibration curve generated during bench-top studies, a separate measurement of three nickel standards in the glove box just prior to the product measurement was performed to ensure the accuracy of the determination. The results of the glove box measurements on the nickel standards are shown in Table 10 and in Figs. 8 and 9. 
Table 10. Glove box absorbance measurements

\begin{tabular}{cccccc}
\hline Sample & \multicolumn{2}{c}{ 1 st peak absorbance } & & \multicolumn{2}{c}{ 2nd peak absorbance } \\
\cline { 2 - 3 } \cline { 5 - 6 } & Target A & Target B & & Target A & Target B \\
\hline $\begin{array}{c}1.25 \\
\text { standard }\end{array}$ & $1.2698 \pm 0.04 \%$ & $1.2838 \pm 0.03 \%$ & $0.54903 \pm 0.02 \%$ & $0.55323 \pm 0.04 \%$ \\
$\begin{array}{c}1.5 \mathrm{M} \\
\text { standard }\end{array}$ & $1.5319 \pm 0.095 \%$ & $1.5429 \pm 0.04 \%$ & $0.66662 \pm 0.01 \%$ & $0.66927 \pm 0.07 \%$ \\
$\begin{array}{c}1.75 \mathrm{M} \\
\text { standard }\end{array}$ & $1.7723 \pm 0.09 \%$ & $1.7851 \pm 0.14 \%$ & $0.78021 \pm 0.03 \%$ & $0.78452 \pm 0.035 \%$ \\
$\begin{array}{c}\text { Product } \\
\text { solution }\end{array}$ & $1.5604 \pm 0.12 \%$ & $1.5472 \pm 0.06 \%$ & $0.68547 \pm 0.12 \%$ & $0.6700 \pm 0.035 \%$ \\
\hline
\end{tabular}

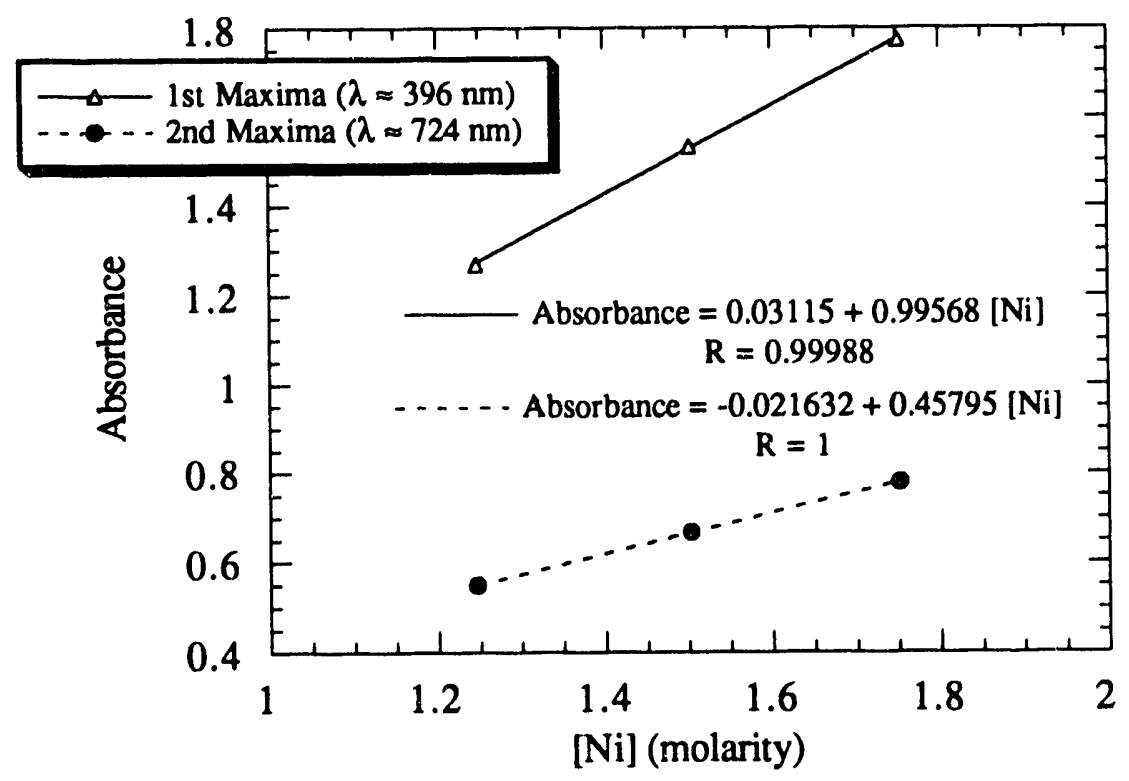

Fig. 8. Beer's law plot for nickel standards measurement, target A. 


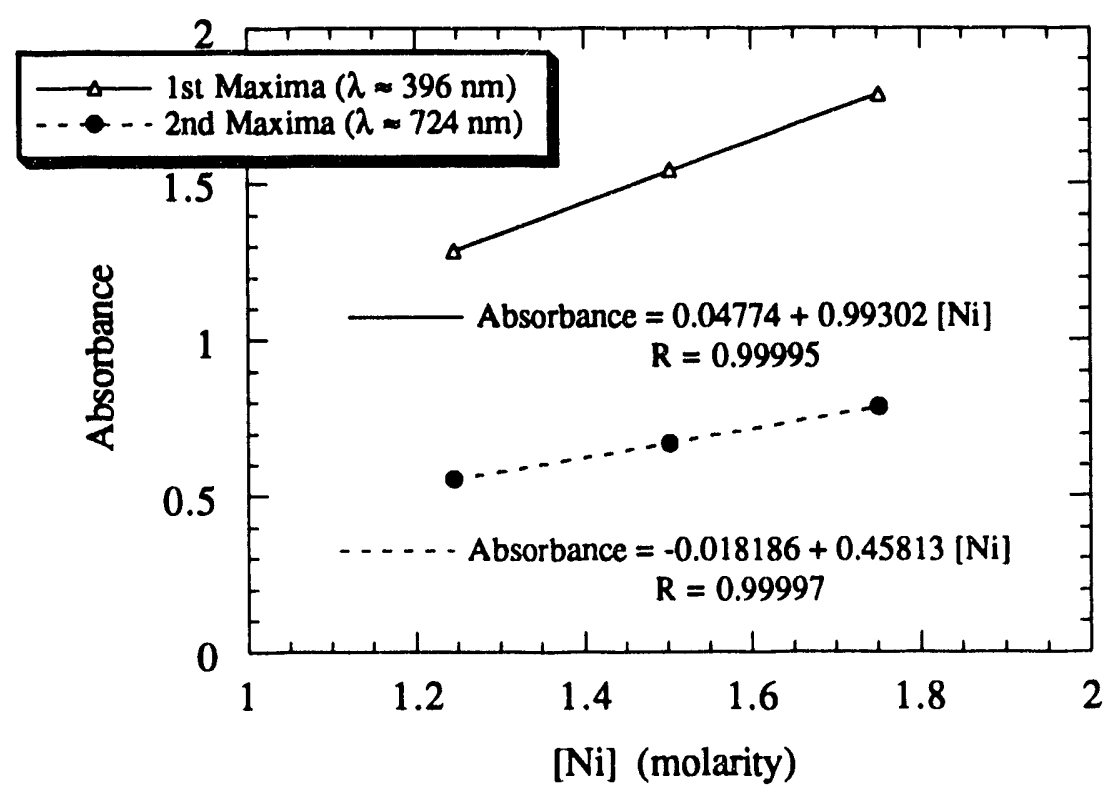

Fig. 9. Beer's law plot for nickel standards measurement, target B.

Although the differences in the absorbance of the sample and reference cells are automatically accounted for in the calibration curve, it is wise to periodically obtain sample and reference cell "blanks"; that is, each cell is filled with reference fluid and measured with respect to an open path in the cell holder. Any significant changes in the relative absorbance of the sample and reference cell will be evident and should be corrected for in subsequent measurements, or a new calibration curve generated. It should also be noted that the measured spectra of the nickel standards and the nickel products were essentially exact overlays (compare Fig. 10 with Fig. 5). The product-nickel concentrations, based upon the regression lines in Figs. 8 and 9 and the measured product absorbances, are documented in Table 11 and show good agreement between the values derived from each absorbance peak. 


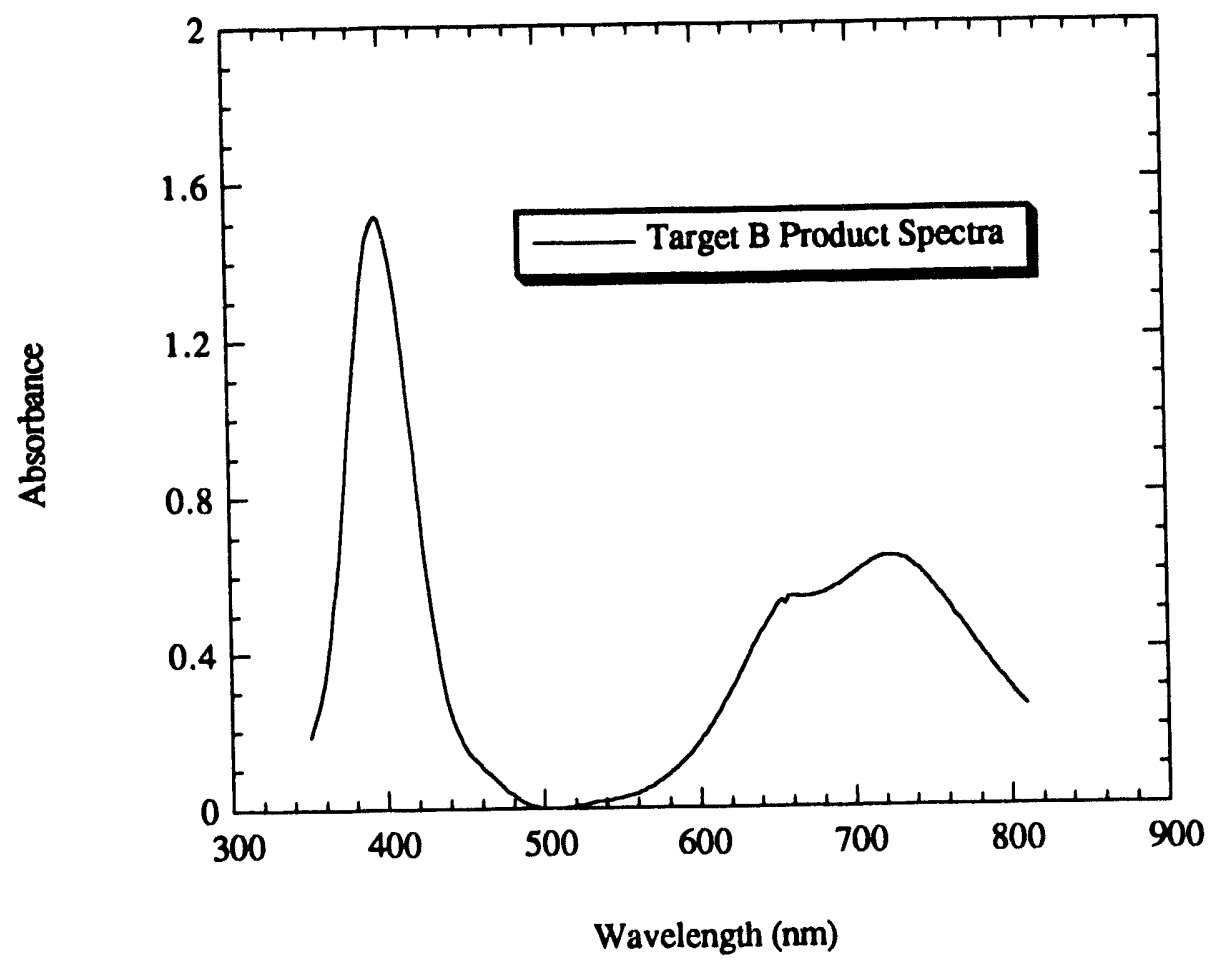

Fig. 10. Spectra of nickel product solution.

Table 11. Product nickel concentrations (in molarity) based upon absorbance measurements

\begin{tabular}{cccc}
\hline Product solution & $\begin{array}{c}\text { [Ni] } \\
\text { based upon 1st peak } \\
\text { absorbance }\end{array}$ & $\begin{array}{c}\text { [Ni] } \\
\text { based upon 2nd peak } \\
\text { absorbance }\end{array}$ & $\begin{array}{c}\text { Reported average } \\
\text { [Ni] }\end{array}$ \\
\hline Target A & 1.536 & 1.544 & $1.540 \pm 0.26 \%$ \\
Target B & 1.510 & 1.5026 & $1.506 \pm 0.35 \%$ \\
\hline
\end{tabular}

In order to convert a measured specific gravity to a nickel concentration (or vice versa), one must account for the effect of enrichment upon the previous gravimetric 
measurements on naturally abundant nickel. Using a projected average nickel atomic weight of 62.1 for the target A product, we can project as follows:

$$
\begin{aligned}
\left\{\begin{array}{c}
\text { Increase in density } \\
\text { due to enrichment }
\end{array}\right\} & =\left(\begin{array}{c}
\text { mass concentration of } \\
\text { natural nickel, 1.54 M }
\end{array}\right) \times\left(\frac{\text { At. wt (enriched) }}{\text { At. wt (natural) }}-1\right) \\
& =(0.09041 \mathrm{~g} \mathrm{Ni} / \mathrm{mL}) \times\left(\frac{62.1}{58.71}-1\right)=0.0052 .
\end{aligned}
$$

Therefore, the $1.54 \underline{\mathrm{M}}$ product solution should have the following density (see Fig. 6):

$$
\rho_{\mathrm{E}}=[0.99951+(0.1124) 1.54]+0.0052=1.178 \mathrm{~g} / \mathrm{mL} \text {. }
$$

A $0.5-\mathrm{mL}$ aliquot of the target A product was weighed and gave a density of $1.172 \mathrm{~g} / \mathrm{mL}$.

\section{DISCUSSION}

\subsection{IMPROVED FLOWSHEET POSSIBILITIES}

One of the shortcomings of the present flowsheet (Fig. 1) is that it does not take advantage of the opportunity to integrate the various process steps and thereby improve and simplify operations. Reversing the order of anion exchange and cation exchange and loading the entire nickel inventory onto cation resin offers the following potential advantages:

1. It provides for a simpler and faster $\mathrm{NO}_{3}{ }^{-}$to $\mathrm{Cl}^{-}$conversion during cation exchange (i.e., load in dilute $\mathrm{HNO}_{3}$, wash with dilute acid, elute nickel with

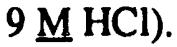

2. It removes monovalent impurities during the cation-exchange column wash. (No step at present accomplishes this.)

3. It automatically removes $\mathrm{Sc}(\mathrm{III})$.

(Scandium is retained on cation resin at high acid.)

4. It provides an opportunity to remove chromium as $\mathrm{Cr}(\mathrm{VI})$ during cation exchange (i.e., as an anion, requires a preliminary oxidation step). 
The cation-exchange equilibria [21] displayed in Figs. 11 and 12 make it clear that a $\mathrm{Ni}$ (II)/Cr(III) separation is at best a difficult proposition. A much more selective approach is to oxidize the chromium to $\mathrm{Cr}(\mathrm{VI})$ and remove it as an anion during the loading and washing of the cation resin. The major drawback with this scheme is the increased processing volume required for a column large enough to load the entire nickel inventory. The only uncertain advantage listed previously is item 4 and again concems the stability of the chromate anion against reduction to $\mathrm{Cr}$ (III). A series of tests at various feed acid concentrations demonstrated that chromium removal during cation exchange is effective for feed acid concentrations below $0.1 \underline{\mathrm{M}}$ (Table 12).

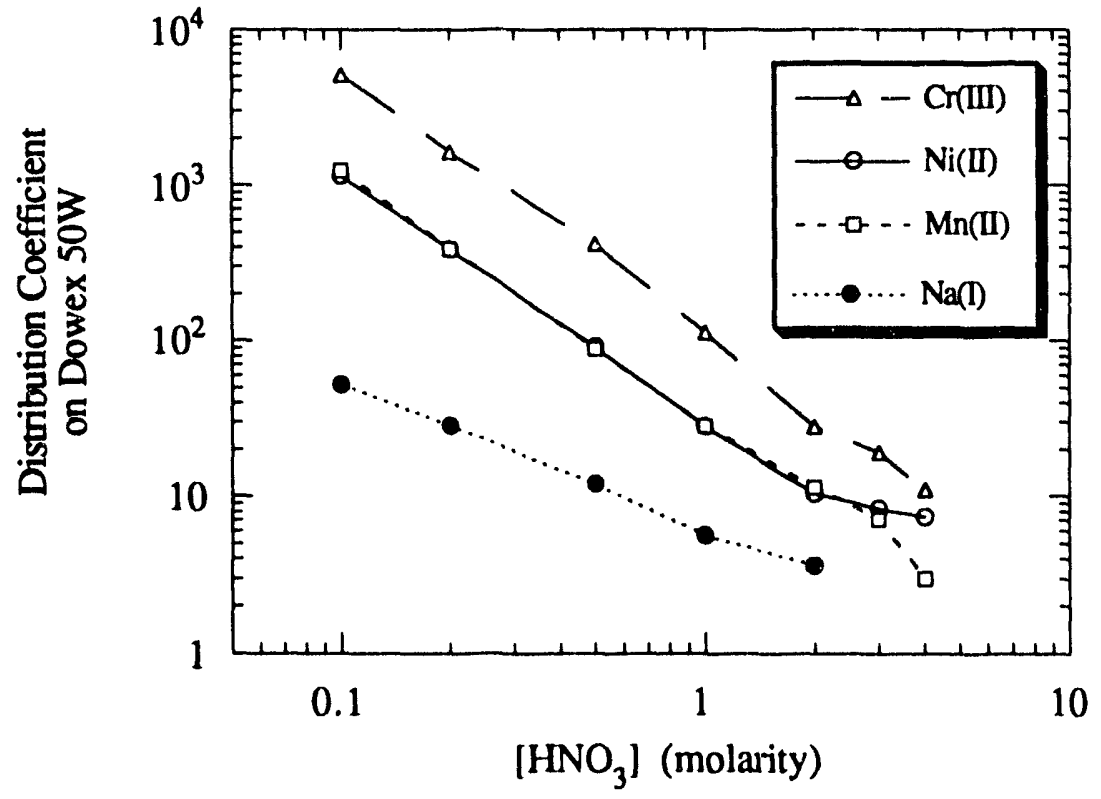

Fig. 11. Distribution coefficients of $\mathrm{Ni}(\mathrm{II}), \mathrm{Mn}(\mathrm{II}), \mathrm{Cr}$ (III), and $\mathrm{Na}$ (I) in $\mathrm{HNO}_{3}$ solutions on cation-exchange resin (Dowex $50 \mathrm{~W}-\mathrm{X} 4$ ). 


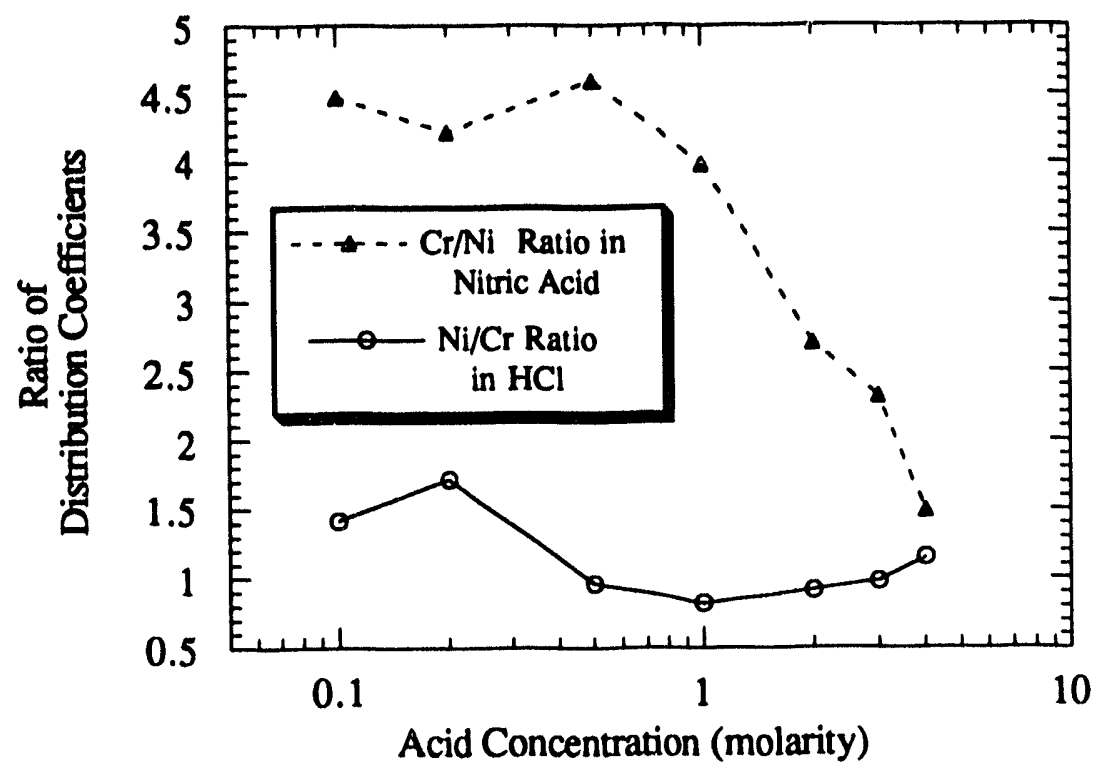

Fig. 12. Ratio of distribution coefficients for $\mathrm{Ni}(\mathrm{II})$ and $\mathrm{Cr}$ (III) in $\mathrm{HNO}_{3}$ and $\mathrm{HCl}$ solutions on cation-exchange resin (Dowex 50W-X4).

A potential improvement which retains the virtue of separations sized based upon impurity levels rather than nickel content is the replacement of the TOPO extraction step with anion-exchange chromium removal. Ion exchange is preferable primarily because it generates smaller and more manageable waste streams. Provisional anion-exchange removal of chromium, as previously described, was only moderately successful. The difficulty with this approach is that chromic acid attacks, and is reduced by, strong-base anion resin $[22,23]$. However, by using a weak acid resin specifically formulated to resist chromic acid attack [24] and operating at very low acid concentrations, good chromium removals can be achieved (Table 12). 
Table 12. Chromium(VI) removal by ion exchange

[Bed volume $(\mathrm{BV})=2 \mathrm{~mL} ; \mathrm{ID}=0.8 \mathrm{~cm}$; flow $\sim 1 \mathrm{~cm} / \mathrm{min}$ ]

\begin{tabular}{|c|c|c|}
\hline \multicolumn{2}{|c|}{$\begin{array}{l}\text { Weak base anion resin: Amberlite IRA-94 } \\
\text { Feed: } 10 \mathrm{BV} 2 \mathrm{mM} \mathrm{K}_{2} \mathrm{Cr}_{2} \mathrm{O}_{7} \\
\text { Product: } 10 \mathrm{BV} \text { loading effluent }+ \\
3 \mathrm{BV} \text { column wash (water) }\end{array}$} & $\begin{array}{l}\text { Strong acid resin: Dowex } 50 \mathrm{~W}-\mathrm{X} \\
\text { Feed: } 2 \mathrm{BV} 13.6 \mathrm{mM} \mathrm{K}_{2} \mathrm{Cr}_{2} \mathrm{O}_{7} \\
\text { Wash: } 6 \mathrm{BV} 0.05 \mathrm{M} \mathrm{HNO}_{3} \\
\text { Product: } 5 \mathrm{BV} \text { of } 9 \underline{\mathrm{M}} \mathrm{HCl} \text { eluate }\end{array}$ \\
\hline $\begin{array}{c}\text { Feed acid } \\
{\left[\mathrm{mM} \mathrm{HNO}_{3}\right]}\end{array}$ & $\begin{array}{l}\mathrm{DF}^{a} \text { for } \mathrm{Cr} \\
\text { (anion resin) }\end{array}$ & $\begin{array}{c}\mathrm{DF}^{a} \text { for } \mathrm{Cr} \\
\text { (cation resin) }\end{array}$ \\
\hline 1 & $>600$ & 220 \\
\hline 10 & 110 & 300 \\
\hline 100 & 70 & 190 \\
\hline
\end{tabular}

${ }^{a}$ Decontamination factor.

\subsection{EVAluation OF TARGeT AND PELlET LEACHES}

Due to the fact that both the target aluminum and the nickel pellets contain similar metallic impurities (and therefore activation products), it is difficult to sort out the effectiveness of individual pellet leaches. However, one can look at the total amount of leached activity, shown in Table 13, and judge whether "significant" activity was removed. For target $\mathrm{A}$, the $0.67 \mathrm{mCi}$ of ${ }^{54} \mathrm{Mn}$ is the only activity which would have followed the nickel into the final product. The same is true of the second target $\left(0.3 \mathrm{mCi}\right.$ of $\left.{ }^{54} \mathrm{Mn}\right)$, although both ${ }^{110 \mathrm{~m}} \mathrm{Ag}$ and ${ }^{124} \mathrm{Sb}$ bled through into the product to a small extent (final activities $<0.1 \mathrm{mCi}$ and $10<\mathrm{DF}<100$ ). Since the radionuclidic purity specification puts a limit of about $1 \mathrm{mCi}$ of nonnickel activity, these leachate removals much be judged as marginally significant.

Obviously, there are other factors which argue for the effective leaching of both the target surface and the pellets. The requirement that the product be virtually free of alpha activity ( $<30 \mathrm{nCi} \alpha$ per $100 \mathrm{Ci}{ }^{63} \mathrm{Ni}$ ) forces one to take every reasonable precaution to prevent and eliminate sources of cross-contamination. Even the relatively small amount of alpha activity $(\sim 5 \mu \mathrm{Ci}$ for target $\mathrm{A})$ removed during the leaching of the target surface is significant. Because of the difficulty in getting reliable estimates of alpha contamination in samples which must be diluted in-cell (Appendix D), it was not possible to track the 
sources of cross-contamination in the subsequent processing. It is not clear whether the cation-exchange column removed a great deal of alpha activity or whether the solution was

Table 13. Total activity (in millicuries) removed by target and pellet leaches

\begin{tabular}{ccc}
\hline Isotope & Target A & Target B \\
\hline Sc-46 & 3.71 & 0.23 \\
Cr-51 & 13.84 & 0.57 \\
Mn-54 & 0.67 & 0.30 \\
Co-57 & - & 0.01 \\
Co-58 & 4.73 & 0.62 \\
Fe-59 & 8.45 & 1.40 \\
Co-60 & 8.33 & 1.01 \\
Zn-65 & 1.02 & 0.75 \\
Sb-124 & - & 0.07 \\
Ce-144 & - & 0.00 \\
Hf-181 & 0.06 & 0.07 \\
W-188 & 0.20 & 0.01 \\
Total mCi & 41.017 & 5.03 \\
\hline
\end{tabular}

maintained free of contamination. Some degree of pellet leaching is also required to satisfy the chemical purity specification, and it is clear that gross amounts of metallic impurities will impair the operation of the anion- and cation-exchange columns. In any event, the pellets should be leached until the surfaces appear "clean" and any nonmagnetic residue is absent.

Finally, it is instructive to review the sequential removal of activity during leaching isotope by isotope. The progressive leaching of isotopes falls into three categories:

(a) those isotopes with a removal pattern characteristic with their presence in both the aluminum heel and the pellets $\left({ }^{46} \mathrm{Sc},{ }^{51} \mathrm{Cr},{ }^{58,60} \mathrm{Co},{ }^{59} \mathrm{Fe}\right.$, and ${ }^{65} \mathrm{Zn}$ ); (b) those isotope(s) with a removal pattern consistent with a predominant presence only in the aluminum heel $\left({ }^{54} \mathrm{Mn}\right)$; and (c) those isotopes with a removal pattem characteristic of target-surface contamination $\left({ }^{181} \mathrm{Hf},{ }^{188} \mathrm{~W}\right)$. These categories of isotopes are displayed in Figs. 13-15 for target A and in Figs. 16 and 17 for target B. An additional piece of information is also displayed in these figures: the projected inventory of isotopes in the refluxed leachates based upon the analysis of the dissolved nickel and the ${ }^{63} \mathrm{Ni}$ assay of these leachates (i.e., 
the inventory of isotopes the leachate would have if it contained the same distribution of isotopes as the dissolved nickel). These projected values serve as benchmarks for the degree to which the boiling leaches effected selective removal of the dissolver heel activity. Note that, for target A, the projected removals of ${ }^{46} \mathrm{Sc},{ }^{58,60} \mathrm{Co},{ }^{59} \mathrm{Fe}$, and ${ }^{65} \mathrm{Zn}$ were all essentially the same as found in the final boiling acid leachate $(\mathrm{P} 5,0.2 \mathrm{M} \mathrm{HCl}):$ no selective removal was achieved but a substantial amount of nickel $(0.465 \mathrm{~g})$ was dissolved. The fact that the projected inventory of ${ }^{54} \mathrm{Mn}$ was far below the measured value confirms the supposition that ${ }^{54} \mathrm{Mn}$ resides primarily in the heel from the dissolved aluminum. For target B, all of these projected values (except ${ }^{124} \mathrm{Sb}$ ) for the boiling acid leach (P3, $0.1 \mathrm{M}$ $\mathrm{HCl}$ ) are far below the measured values and reflect the selective removal of the activation associated with the dissolver heel from the nickel pellets. It is safer and more effective to leach with a more dilute $\mathrm{HCl}$ solution $(\leq 0.1 \mathrm{M})$ at reflux, since this ensures good contacting while limiting the potential (stoichiometrically) for nickel dissolution. 

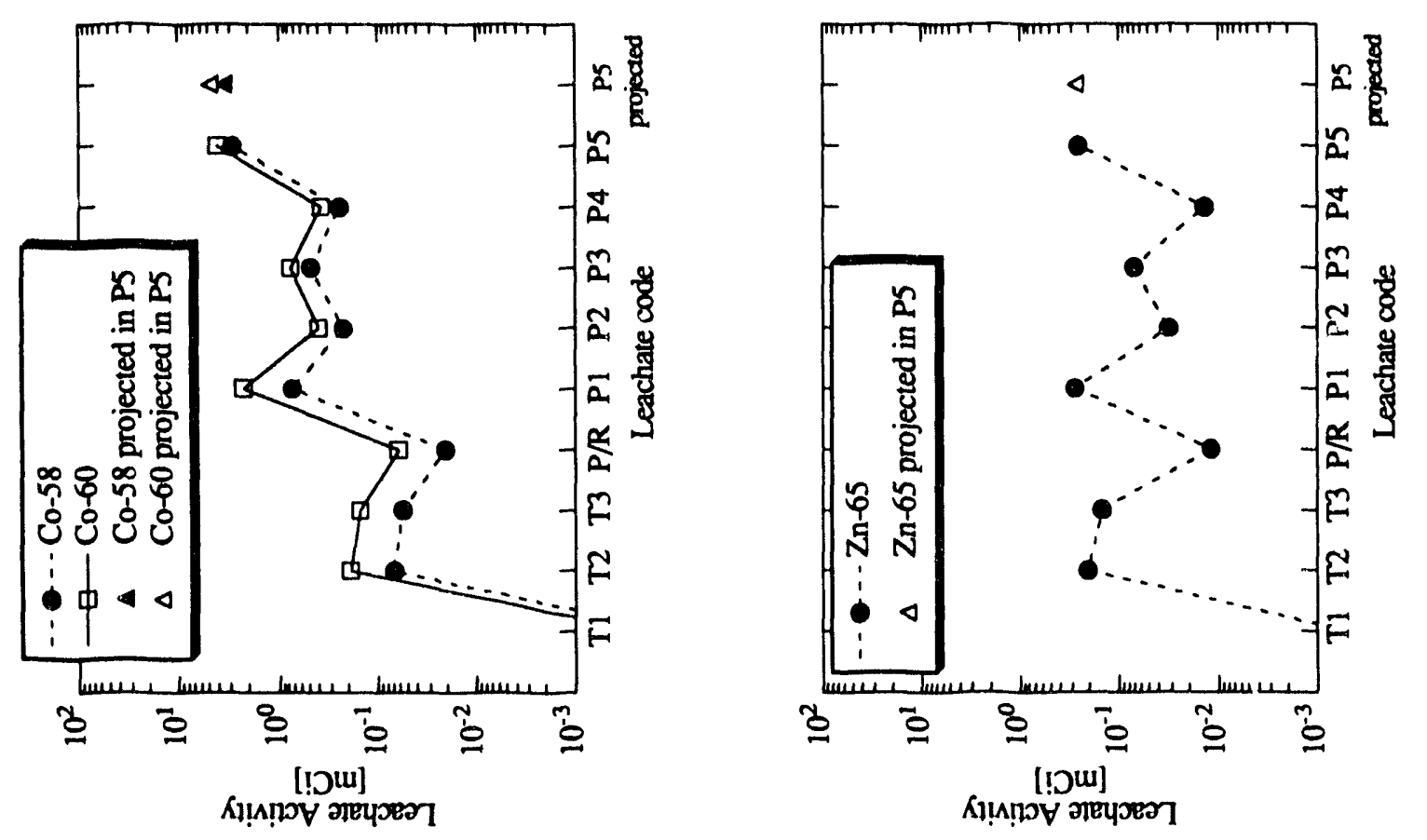

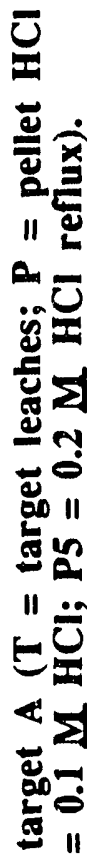
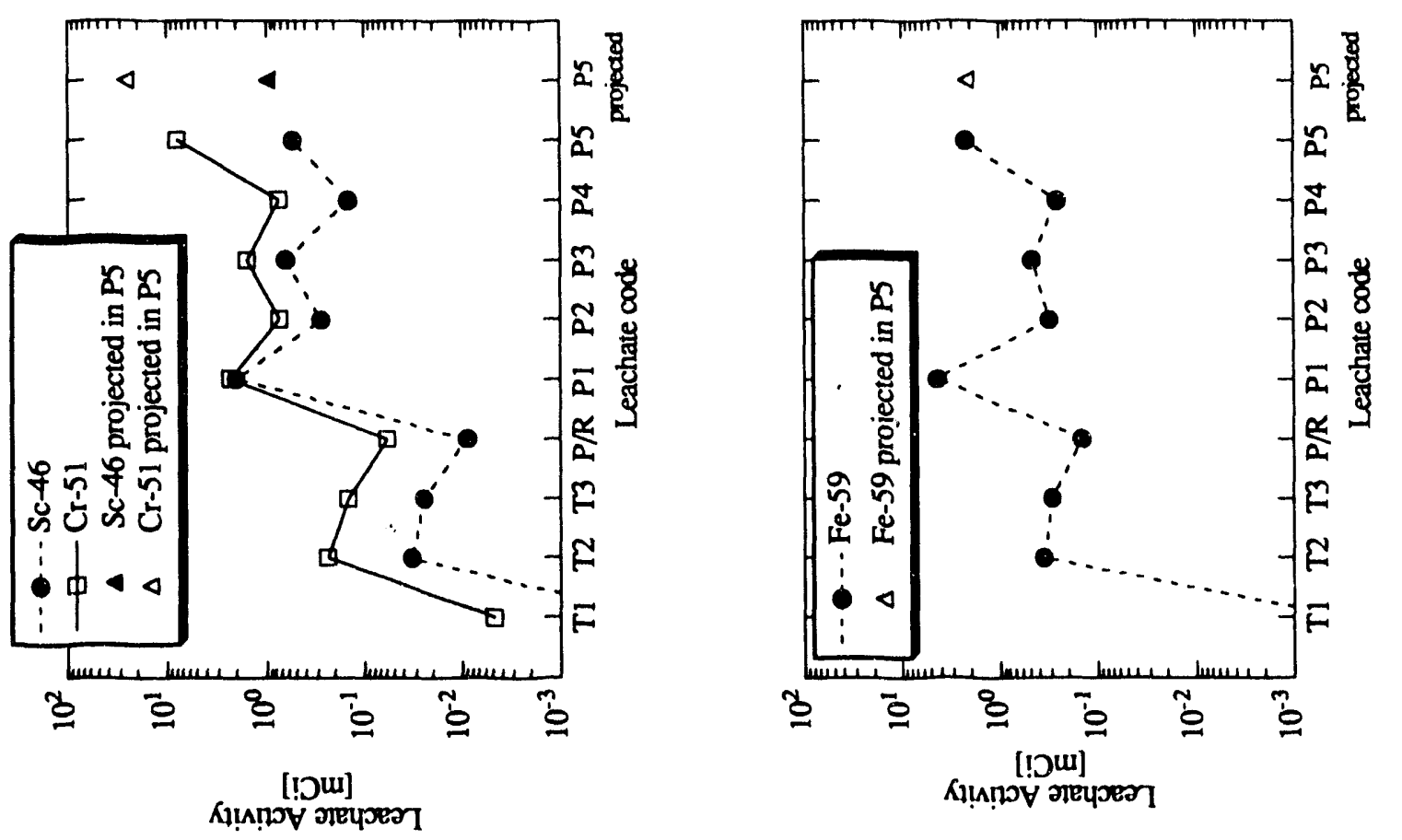

造

볼 


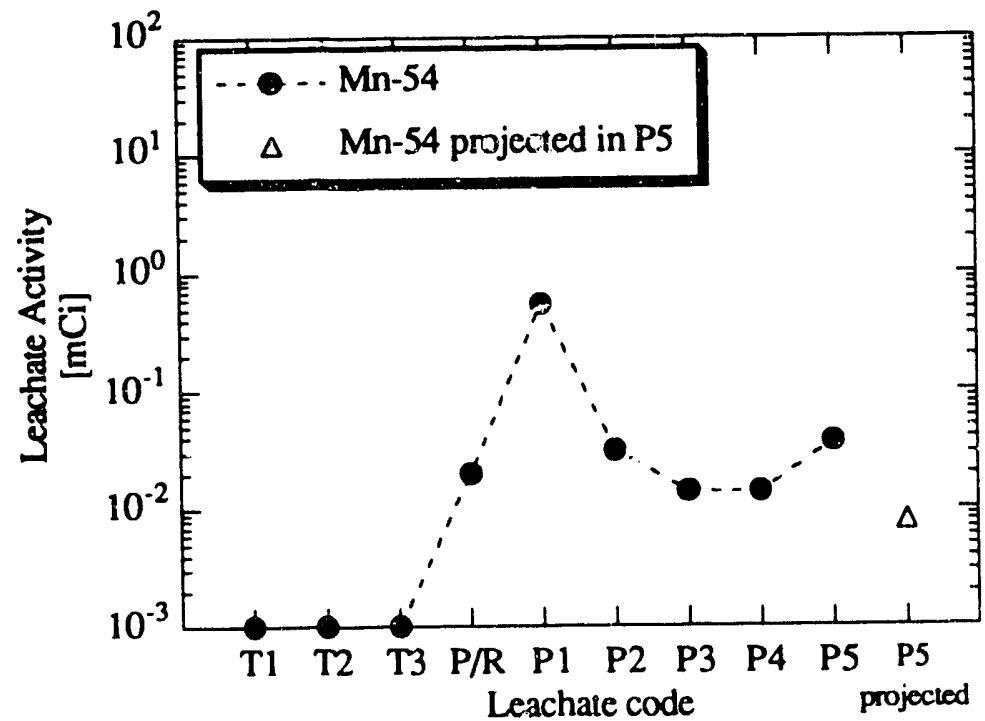

Fig. 14. Sequential removal of category (b) isotopes, target $A(T=$ target leaches; $P=$ pellet $\mathrm{HCl}$ leaches: $P / R=$ water rinse; $P 1, P 3=0.5 \mathrm{M}$ $\mathrm{HCl}$; 2 2, P4 = 0.1 M HCl; P5 =0.5 M. HCl reflux).

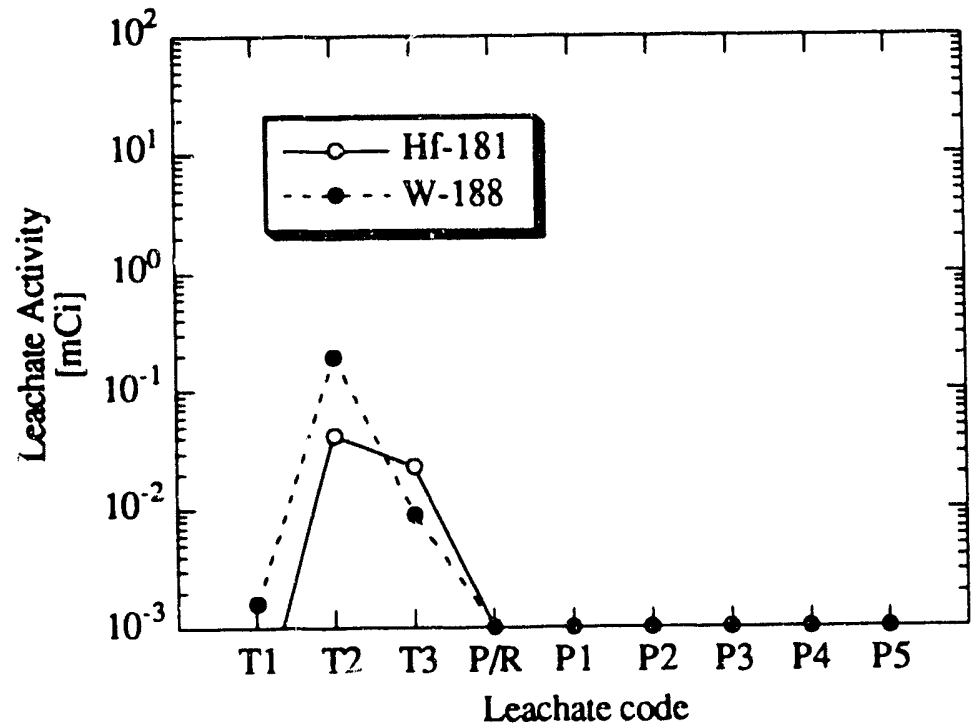

Fig. 15. Sequential removal of category (c) isotopes, target $A(T=$ target leaches; $\mathrm{P}=$ pellet $\mathrm{HCl}$ leaches: $\mathrm{P} / \mathrm{R}=$ water rinse; $\mathrm{P} 1, \mathrm{P3}=0.5 \mathrm{M}$ HCl; P2, P4 $=0.1 \underline{\mathrm{M}} \mathrm{HCl}$; P5 $=0.5 \underline{\mathrm{MCl}}$ reflux). 

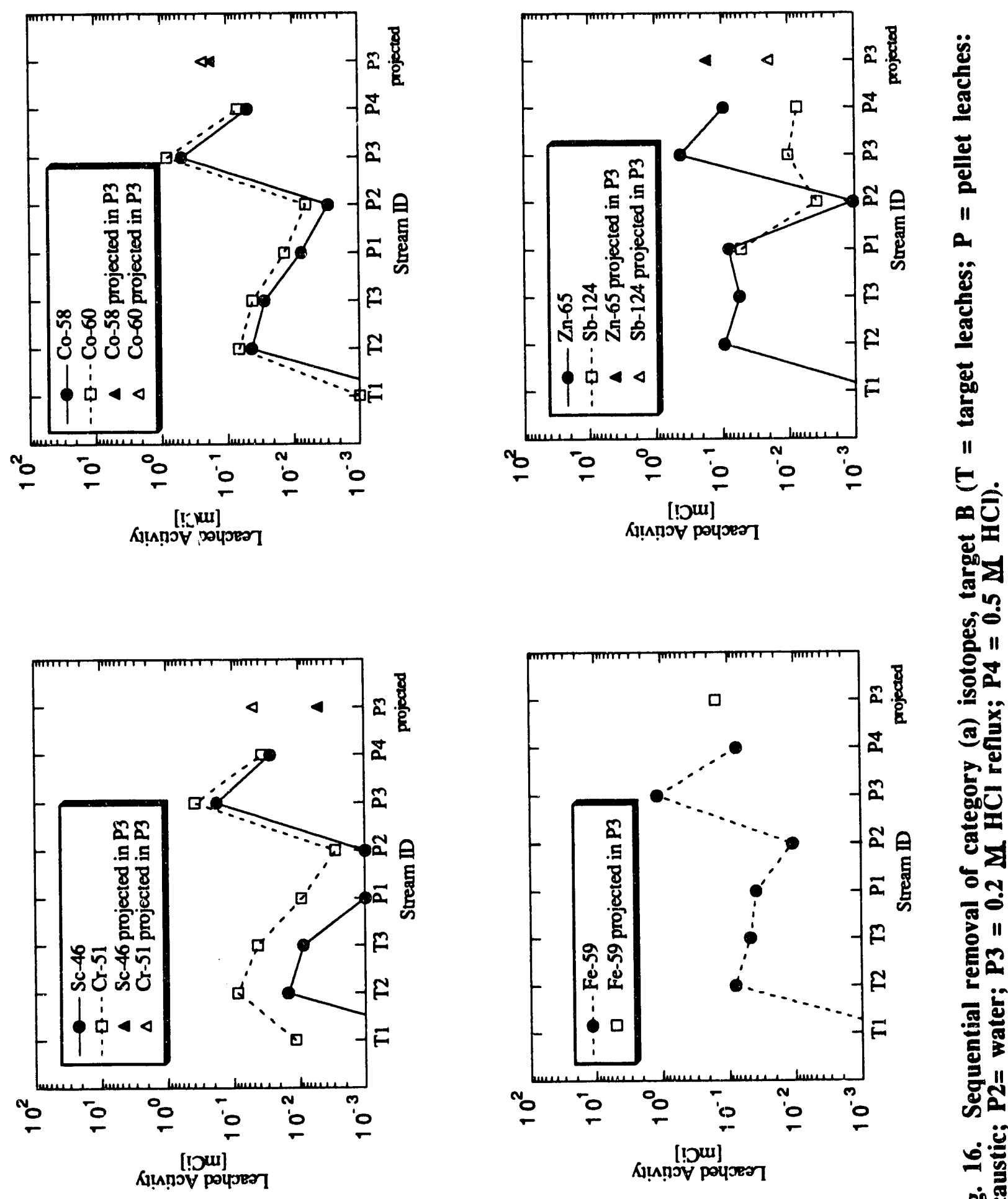

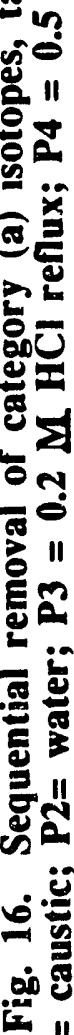




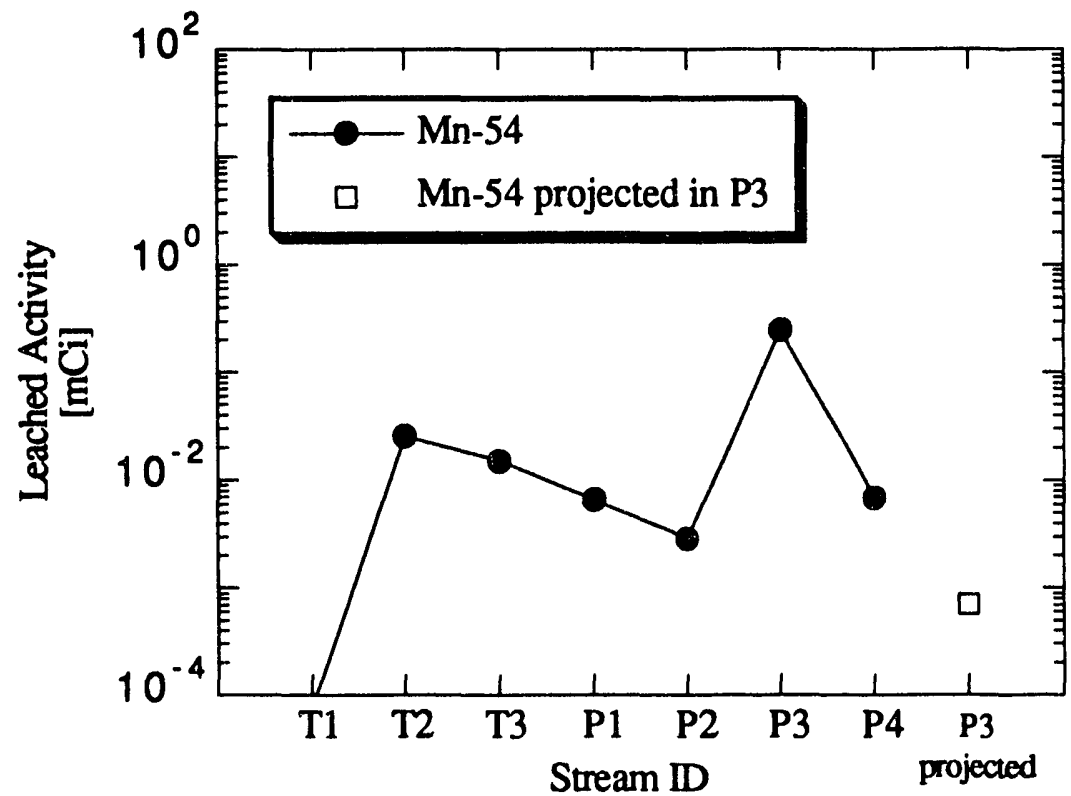

Fig. 17. Sequential removal of category (b) isotopes, target $B$ ( $T=$ target leaches; $P=$ pellet leaches: $P 1=$ caustic; $P 2=$ water; $P 3=0.2 \mathrm{M} \mathrm{HCl}$ reflux; $\mathrm{P4}=0.5 \mathrm{M} \mathrm{HCl}$ ). 


\section{ACKNOWLEDGMENTS}

This work would not have been possible without the timely support of the Analytical Chemistry Division, and John Keller in particular. 


\section{REFERENCES}

1. Ujihara, Y., "Simple Cell for Electro-deposition of Radioactive Sources," Can. J. Chem. 46, p. 1221 (1968).

2. Petek, M. et al., Plating Nickel-63 on Copper Coupons, Oak Ridge National Laboratory, ORNL/TM-10989 (1989).

3. Ayala, J. A. and Wentworth, W. E., "Comparative Investigation of Radioactive Sources for the Electron Capture Detector," J. Chromatog. 195, p. 1 (1980).

4. Timset, R. S., "Ni-63 Source for Determination of the Thickness of Supported Metallic Films," Thin Solid Films 47, p. 323 (1977).

5. Gallant, J. L. "Preparation of ${ }^{3} \mathrm{H},{ }^{63} \mathrm{Ni},{ }^{14} \mathrm{C}$ Large Area Sources for Document Imaging," Nucl. Inst. A 257, p. 79 (1987).

6. Singer, S. E. and Kurbatov, M. H., "Radiochemical Purification of Nickel in Macro Quantities," J. Am. Chem. Soc. 76, p. 4739 (1954).

7. Kirby, L. J., Radiochemistry of Nickel, Subcommittee on Radiochemistry of the National Academy of Sciences - National Research Council, NAS-NS-3051 (1961).

8. Kraus, K. A. and Moore, G. E., "Anion Exchange Studies VI: The Divalent Transition Elements Manganese to Zinc in Hydrochloric Acid," J. Am. Chem. Soc. 75, p. 1460 (1953).

9. Kraus, K. A. and Nelson, F., “Anion Exchange Studies of Metal Complexes," in: The Structure of Electrolytic Solutions (W. J. Hamer, ed.), John Wiley \& Sons, Inc., New York, p. 340 (1959).

10. Bigelow, J. E. et al., "Production of Transplutonium Elements in the High Flux Isotope Reactor," in: Transplutonium Elements - Production and Recovery (J. D. Navratil and W. W. Schulz, eds.), American Chemical Society, p. 6 (1981).

11. Martens, R. I. et al., "Preparation of Aluminum Clad Fuels for Solvent Extraction," in: Nuclear Engineering Part XI (F. J. Van Antwerpen, ed.), p. 44 (1964).

12. Kajima, S., "Liquid Scintillation Counting of Low-Activity ${ }^{63} \mathrm{Ni}$," J. Radioanal. Nucl. Chem. Letters 95, p. 323 (1985).

13. Yonezawa, C. et al., "Rapid Determination of Specific Activity of Nickel-63," J. Radioanal. Chem. 78, p. 7 (1983).

14. King, L. J. et al., Safety Analysis: Transuranium Processing Plant, Building 7920, Oak Ridge National Laboratory, ORNL/TM-7688 (1985).

15. Cotton, F. A. and Wilkinson, G., Advanced Inorganic Chemistry, 3rd ed., Interscience Publishers, New York, p. 594 (1972).

16. Pijck, J., Radiochemistry of Chromium, Subcommittee on Radiochemistry of the National Academy of Sciences - National Research Council, NAS-NS-3007 (1964).

17. White, J. C. and Ross, W. J., Extraction of Chromium with Trioctylphosphine Oxide, Oak Ridge National Laboratory (ORNL), ORNL-2326 (1957). 
18. White, J. C. and Ross, W. J., Separations by Solvent Extraction with Tri-noctylphosphine Oxide, Subcommittee on Radiochemistry of the National Academy of Sciences - National Research Council, NAS-NS-3102 (1961).

19. Buchanen, B. R. et al., Savannah River Site Instrument Control Programs and Data Reduction Programs Manual, Savannah River Laboratory, WSRC-TR-91-0103 (1991).

20. van Hare, D. R. and Prather, W. S., Fiber Optic Modification of a Diode Array Spectrometer, Savannah River Laboratoy, DP-1714 (1986).

21. Massart, D. L., Cation-Exchange Techniques in Radiochemistry, Subcommittee on Radiochemistry of the National Academy of Sciences - National Research Council, NAS-NS-3113 (1971).

22. Sussman, S. et al., "Metal Recovery by Anion Exchange," Ind. Eng. Chem. 37, p. 618 (1945).

23. Morrison, W. S., "Chromium Recovery from Plating Solutions," in: Ion Exchange Technology (F. C. Nachod and J. Schubert, eds.), Academic Press, New York, p. 321 (1956).

24. Kunin, R., New Technology for the Recovery of Chromates from Cooling Tower Blowdown, Rohm and Haas Co., Industrial Chemicals, Fluid Process Chem.

Dept., Amber-hi-lites Report 151 (1976). 
Appendix A. DIAGRAM OF INDEXING JIG FOR SECTIONING ${ }^{63} \mathrm{Ni}$ TARGETS 
5. Target Rod, 3/8-in. OD

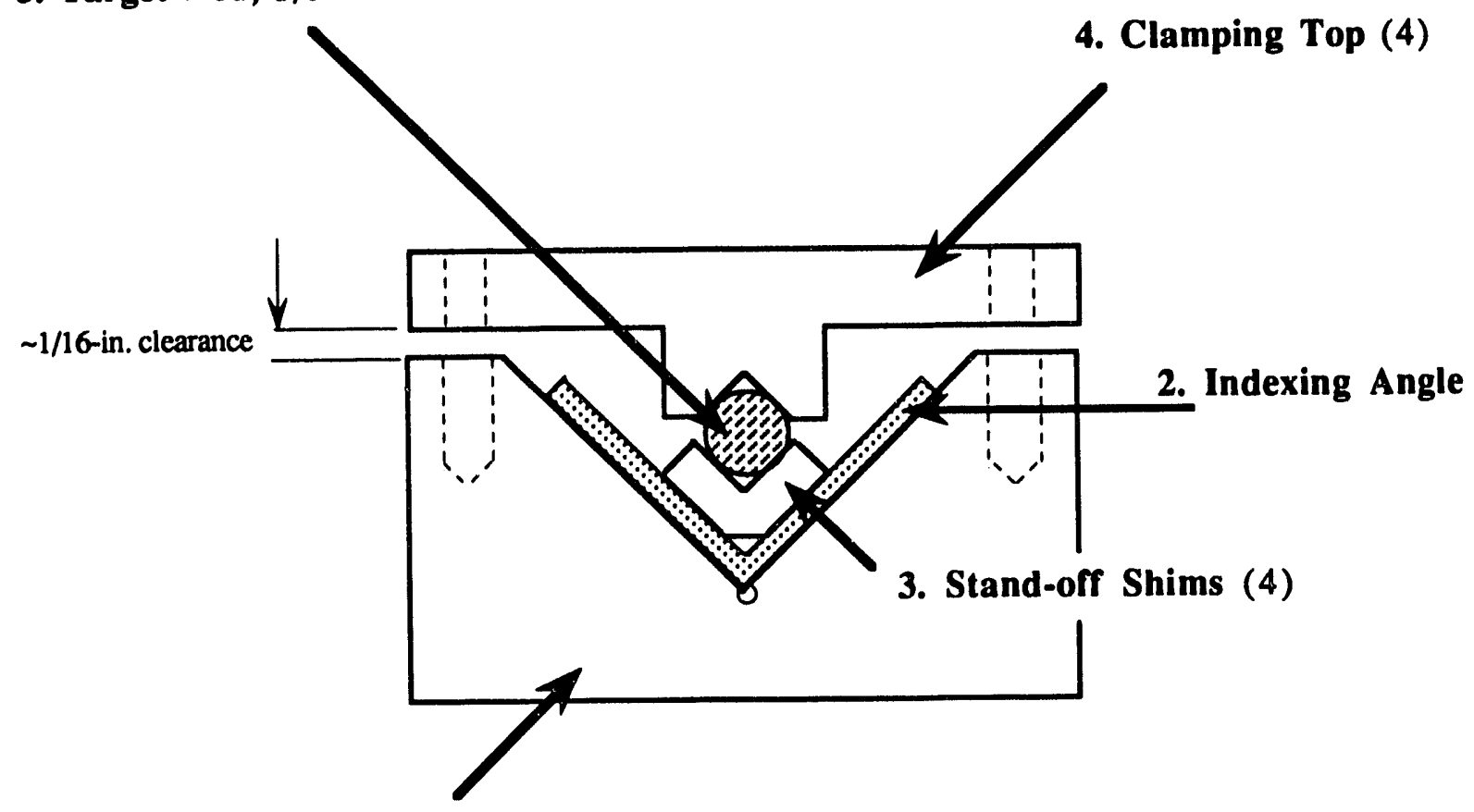

1. V-block Base (4)

Fig. A.1. Diagram of indexing jig for sectioning ${ }^{63} \mathrm{Ni}$ targets. Number required is indicated parenthetically. 


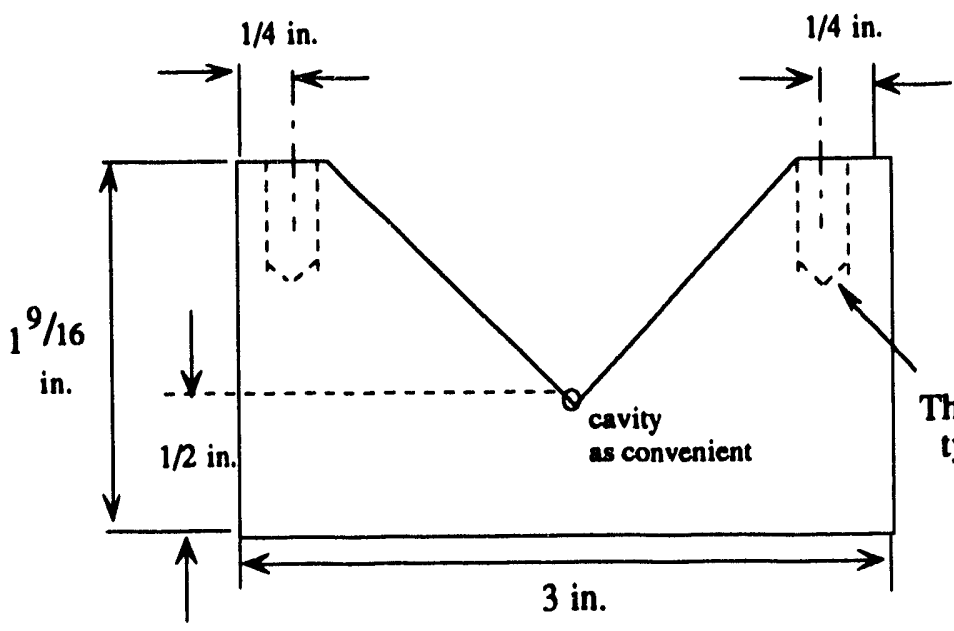

Thread for $1 / 4-20$

typical of two,

$1 / 2$-in. depth

\section{V-BLOCK BASE}

(300 series SS)

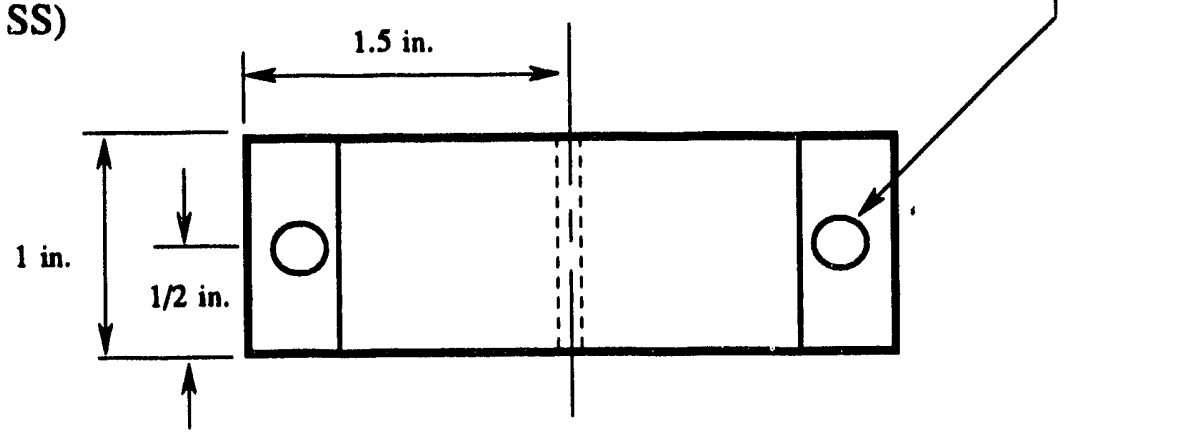

Fig. A.1 (continued) 


\section{INDEXING ANGLE}

(Aluminum Angle: $1.25 \times 1.25 \times 1 / 8$ in., 24-in. length)

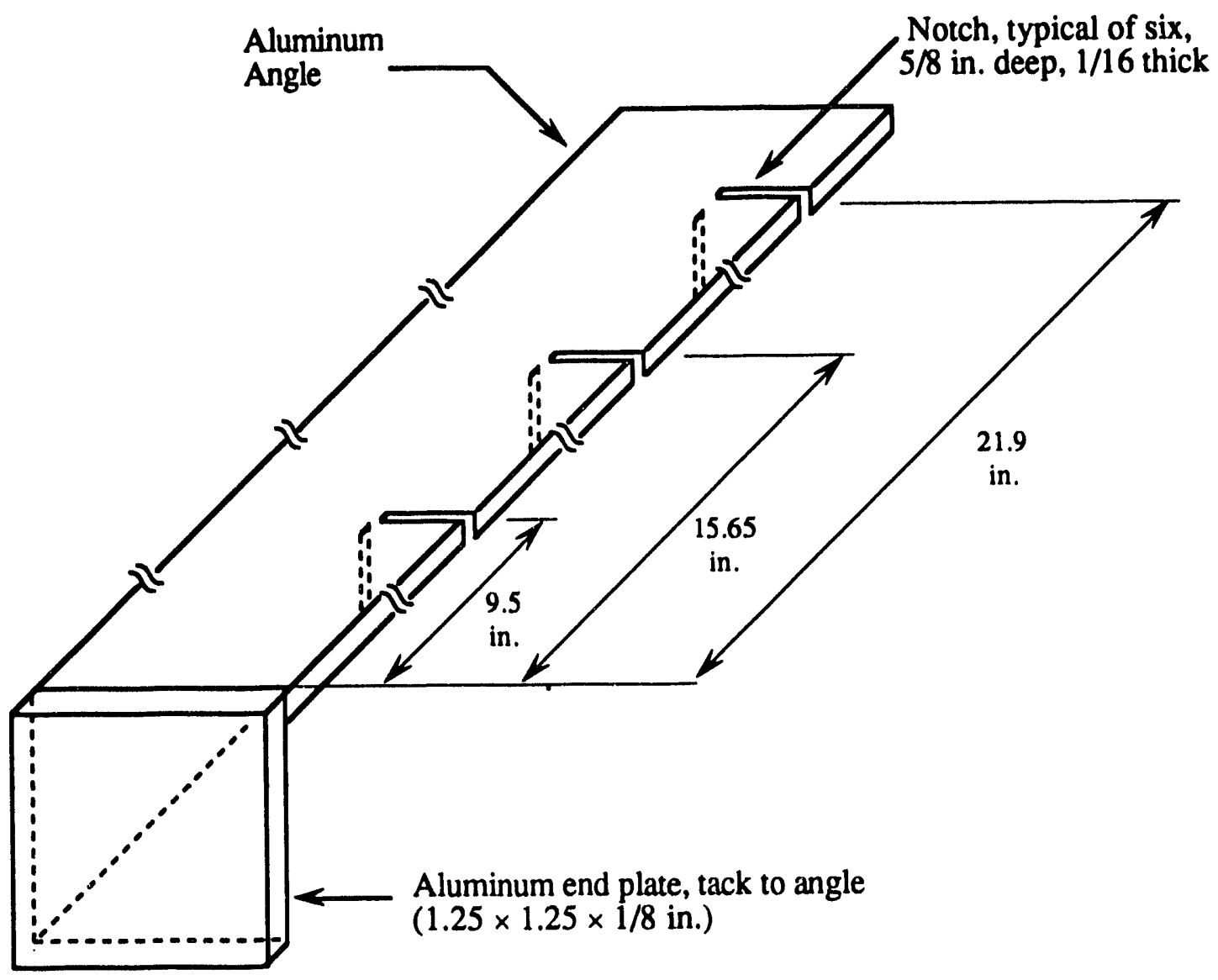

Fig. A.1 (continued) 
4. CLAMPING TOP (Mat'l: 300 ser:es SS)

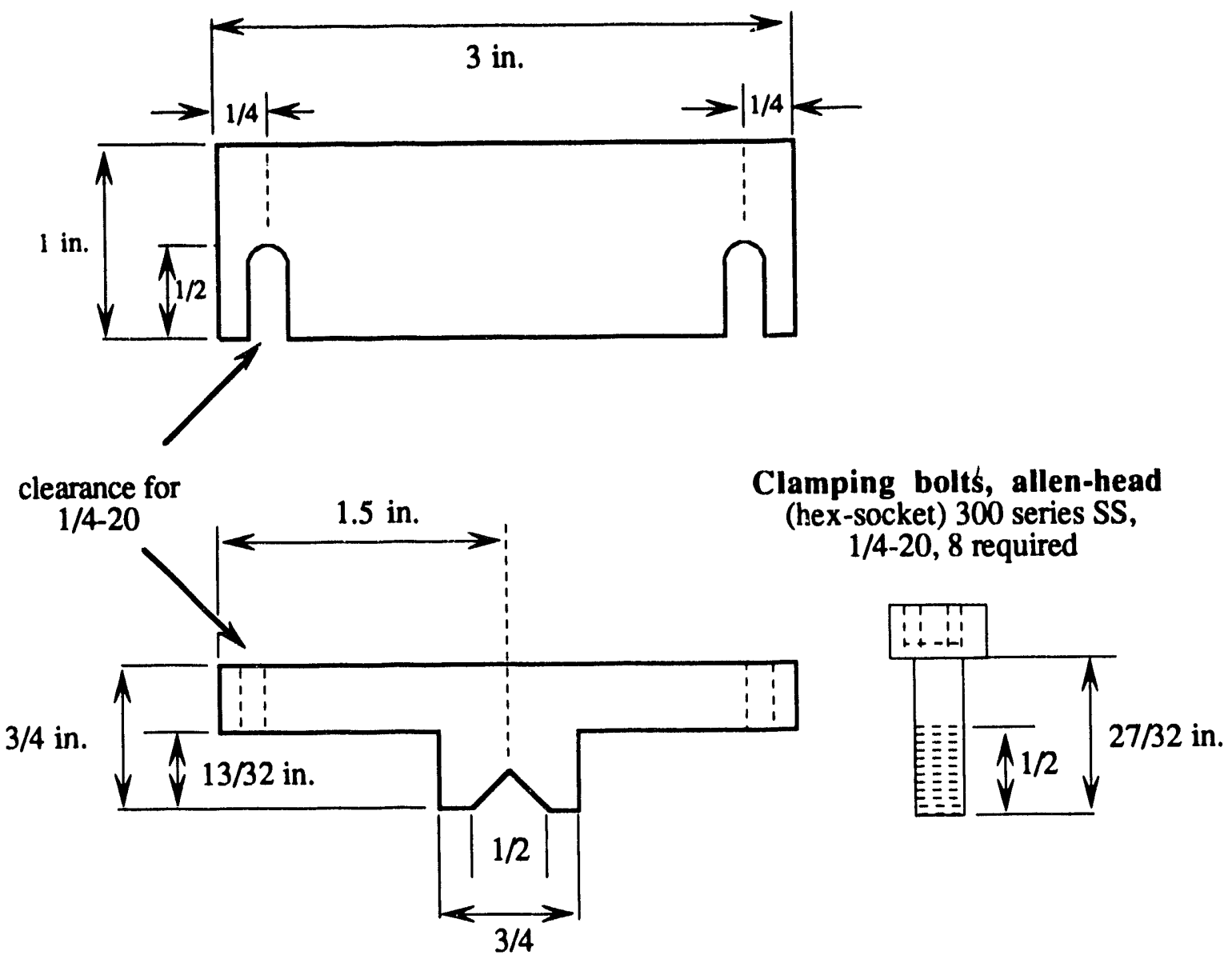

Fig. A.1 (continued) 
3. STANDOFF DETAILS

FOR ANGLE (4 total)

(tacked to angle)
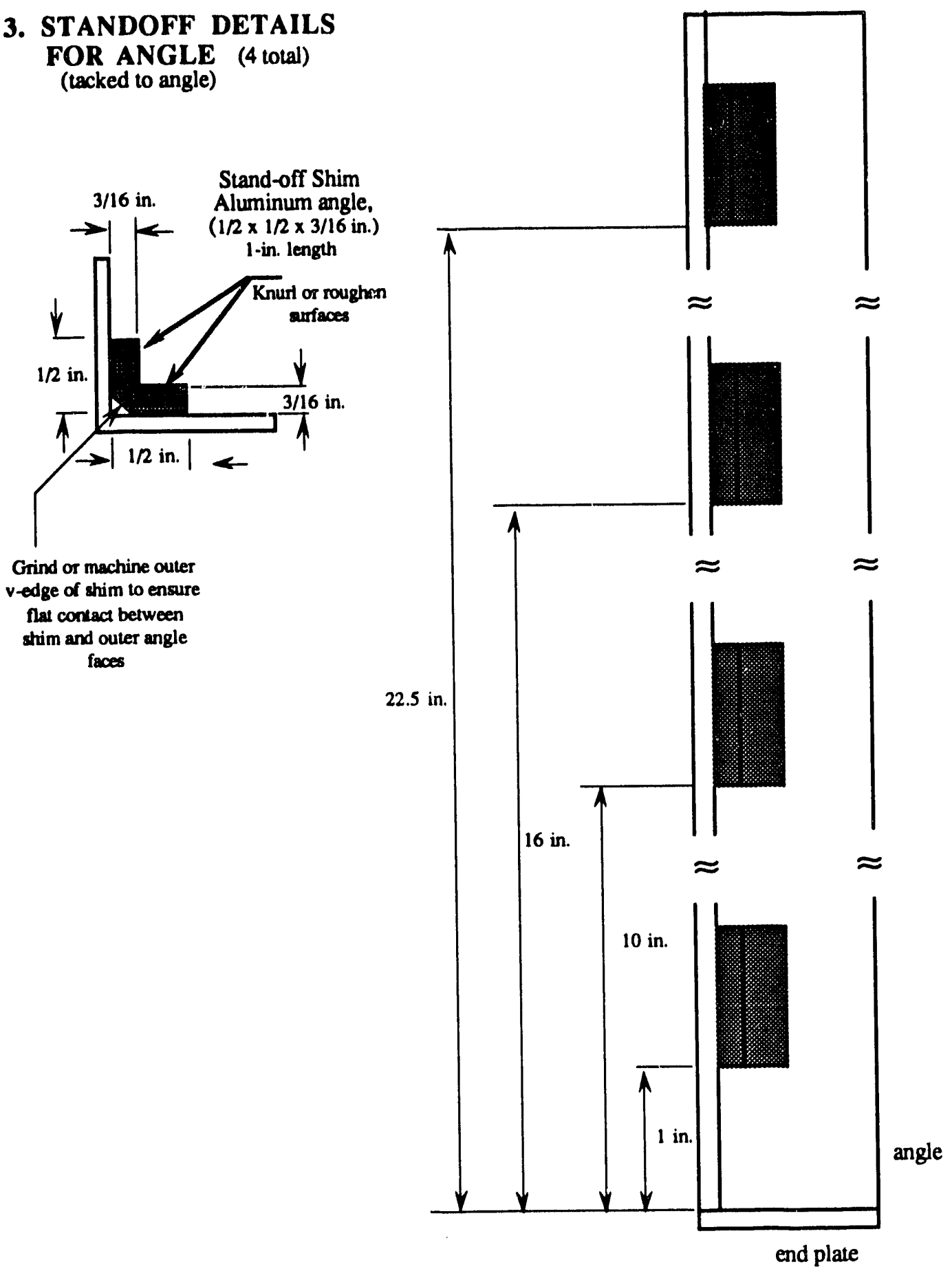

Fig. A.1 (continued) 
Appendix B. SUMMARY OF TARGET LEACHING RESULTS 
Table B.1 Segment leaching results (in millicuries), target A

\begin{tabular}{ccccc}
\hline Isotope & Ethanol leach & $0.5 \mathrm{M} \mathrm{HCl} \mathrm{leach}$ & $\begin{array}{c}0.1 \mathrm{M} \mathrm{HCl} \\
\text { leach }\end{array}$ & $\begin{array}{c}\text { Total leached } \\
\text { activity }\end{array}$ \\
\hline Sc-46 & - & 0.033 & 0.025 & 0.058 \\
Cr-51 & $4.8 \mathrm{E}-03$ & 0.237 & 0.148 & 0.390 \\
Co-58 & - & 0.070 & 0.057 & 0.126 \\
Fe-59 & $2.8 \mathrm{E}-04$ & 0.359 & 0.291 & 0.650 \\
Co-60 & $1.8 \mathrm{E}-04$ & 0.192 & 0.151 & 0.343 \\
Zn-65 & $4.6 \mathrm{E}-04$ & 0.205 & 0.149 & 0.355 \\
Hf-181 & $2.2 \mathrm{E}-04$ & 0.042 & 0.023 & 0.065 \\
W-188 & $1.6 \mathrm{E}-03$ & 0.193 & 0.009 & 0.204 \\
Total (mCi) & 0.0075 & 1.330 & 0.853 & 2.191 \\
Gross alpha & 10 & 662 & 40 & - \\
(Bq/mL) & 10 & 250 & 250 & - \\
Volume (mL) & 250 & 250 & & \\
\hline
\end{tabular}

Table B.2 Segment leaching results (in millicuries), target B

\begin{tabular}{ccccc}
\hline Isotope & Ethanol leach & $0.5 \underline{\mathrm{M} \mathrm{HCl} \text { leach }}$ & $\begin{array}{c}0.1 \mathrm{M} \mathrm{HCl} \\
\text { leach }\end{array}$ & $\begin{array}{c}\text { Total leached } \\
\text { activity }\end{array}$ \\
\hline Sc-46 & $5.20 \mathrm{E}-05$ & 0.015 & 0.009 & 0.024 \\
$\mathrm{Cr}-51$ & $1.15 \mathrm{E}-02$ & 0.088 & 0.043 & 0.143 \\
$\mathrm{Mn}-54$ & $7.43 \mathrm{E}-05$ & 0.025 & 0.015 & 0.040 \\
Co-57 & - & 0.001 & - & 0.001 \\
Co-58 & $1.42 \mathrm{E}-04$ & 0.044 & 0.028 & 0.072 \\
Fe-59 & $2.03 \mathrm{E}-04$ & 0.081 & 0.047 & 0.129 \\
Co-60 & - & 0.068 & 0.043 & 0.110 \\
Zn-65 & $4.26 \mathrm{E}-04$ & 0.095 & 0.055 & 0.150 \\
Cs-137 & $3.04 \mathrm{E}-05$ & - & - & $3.04 \mathrm{E}-05$ \\
Ce-144 & $1.22 \mathrm{E}-03$ & 0.028 & - & 0.030 \\
Hf-181 & $3.31 \mathrm{E}-04$ & 0.007 & - & 0.008 \\
Total (mCi) & 0.014 & 0.451 & 0.240 & 0.706 \\
Volume $(\mathrm{mL})$ & 250 & 250 & 250 & - \\
\hline
\end{tabular}


Appendix C. ALUMINUM DISSOLUTION BASIS 
Table C.1 Inventory of aluminum and alloying elcments in sectioned target segments (in grams unless otherwise noted)

\begin{tabular}{lllc}
\hline Element & \multicolumn{1}{c}{8001 Aluminum } & 1100 Aluminum & Total $(\mathrm{g})$ \\
\hline $\mathrm{Al}$ & $31.35(98.1 \%)$ & $20.378(99.2 \%)$ & $51.73^{a}$ \\
$\mathrm{Ni}$ & $0.351(1.1 \%)$ & & 0.351 \\
$\mathrm{Fe}$ & $0.160(0.5 \%)$ & $0.111(0.54 \%)$ & 0.271 \\
$\mathrm{Si}$ & $0.0351(0.11 \%)$ & $0.023(0.11 \%)$ & 0.0581 \\
$\mathrm{Cu}$ & $0.0256(0.08 \%)$ & $0.0123(0.06 \%)$ & 0.0379 \\
$\mathrm{Mg}$ & $0.0064(0.02 \%)$ & $0.00411(0.02 \%)$ & 0.0105 \\
$\mathrm{Ti}$ & $0.0054(0.017 \%)$ & $0.00411(0.02 \%)$ & 0.00954 \\
$\mathrm{Cr}$ & $0.0064(<0.02 \%)$ & $0.00411(0.02 \%)$ & 0.0105 \\
$\mathrm{Mn}$ & $0.0064(<0.02 \%)$ & $0.00205(0.01 \%)$ & 0.00844 \\
$\mathrm{Zn}$ & $0.0064(<0.02 \%)$ & $0.00205(0.01 \%)$ & 0.00844 \\
$\mathrm{Co}$ & $0.021 \mathrm{mg}(0.65 \mathrm{ppm})$ & $0.012 \mathrm{mg}(0.58 \mathrm{ppm})$ & $3.3 \times 10^{-5}$ \\
$\mathrm{Total}$ & $31.95(20.55$ & 52.5 \\
\hline
\end{tabular}

$a_{\text {The }} 51.73 \mathrm{~g}$ of aluminum in the two 6-in. target segments was charged to a dissolver containing $440 \mathrm{~mL}$ of $25 \mathrm{wt} \% \mathrm{NaNO}_{3}$. Dissolution occurred at reflux during the stepwise addition of $200 \mathrm{~mL}$ of $50 \mathrm{Nt} \%$ $\mathrm{NaOH}$. 
Appendix D. SUMmary OF NICKel PELlet leACHING ReSUltS 
Table D.1 Results from acid leaches of nickel pellets (in millicuries), target $\mathbf{A}$

\begin{tabular}{cccccccc}
\hline Isotope & $\begin{array}{c}\text { Water } \\
\text { reflux }\end{array}$ & $\begin{array}{c}0.5 \underline{\mathrm{M}} \\
\text { HCl leach }\end{array}$ & $\begin{array}{c}0.1 \underline{\mathrm{M}} \\
\text { HCl leach }\end{array}$ & $\begin{array}{c}0.5 \underline{\mathrm{M}} \\
\text { HCl leach }\end{array}$ & $\begin{array}{c}0.1 \underline{\mathrm{M}} \\
\text { HCl leach }\end{array}$ & $\begin{array}{c}0.2 \underset{\mathrm{M}}{\mathrm{HCl}} \\
\text { relfux }\end{array}$ & $\begin{array}{c}\text { Total } \\
\text { activity }\end{array}$ \\
\hline Sc-46 & 0.009 & 2.027 & 0.280 & 0.645 & 0.148 & 0.545 & 3.65 \\
$\mathrm{Cr}-51$ & 0.059 & 2.338 & 0.743 & 1.574 & 0.757 & 7.978 & 13.45 \\
$\mathrm{Mn}-54$ & 0.020 & 0.552 & 0.031 & 0.014 & 0.014 & 0.037 & 0.67 \\
Co-58 & 0.021 & 0.736 & 0.225 & 0.480 & 0.248 & 2.895 & 4.61 \\
Fe-59 & 0.145 & 4.365 & 0.309 & 0.468 & 0.259 & 2.254 & 7.80 \\
Co-60 & 0.062 & 2.250 & 0.403 & 0.770 & 0.380 & 4.119 & 7.98 \\
Zn-65 & 0.012 & 0.280 & 0.032 & 0.071 & 0.014 & 0.257 & 0.67 \\
$\begin{array}{c}\text { Total } \\
\text { Volume } \\
\text { (mL) }\end{array}$ & 0.328 & 12.549 & 2.023 & 4.022 & 1.820 & 18.085 & 38.83 \\
\hline
\end{tabular}

Table D.2 Results from acid leaches of nickel pellets (in millicuries), target $B$

\begin{tabular}{ccccccc}
\hline Isotope & $\begin{array}{c}\text { Dissolved } \\
\mathrm{Al}\end{array}$ & $\begin{array}{c}\text { Caustic } \\
\text { rinse }\end{array}$ & Water reflux & $\begin{array}{c}0.1 \underline{\mathrm{M}} \mathrm{HCl} \\
\text { reflux }\end{array}$ & $\begin{array}{c}0.5 \underline{\mathrm{M}} \mathrm{HCl} \\
\text { leach }\end{array}$ & $\begin{array}{c}\text { Total leached } \\
\text { activity }\end{array}$ \\
\hline Sc-46 & 3.38 & - & - & 0.176 & 0.027 & 0.203 \\
$\mathrm{Cr}-51$ & - & 0.009 & $2.77 \mathrm{E}-03$ & 0.378 & 0.036 & 0.417 \\
$\mathrm{Mn}-54$ & 1.86 & 0.006 & $2.84 \mathrm{E}-03$ & 0.243 & 0.007 & 0.253 \\
Co-57 & 0.10 & - & $6.08 \mathrm{E}-05$ & 0.009 & - & 0.009 \\
Co-58 & 3.89 & 0.008 & $2.91 \mathrm{E}-03$ & 0.486 & 0.049 & 0.538 \\
Fe-59 & 8.95 & 0.038 & $1.08 \mathrm{E}-02$ & 1.149 & 0.074 & 1.234 \\
Co-60 & 5.91 & 0.014 & $6.35 \mathrm{E}-03$ & 0.811 & 0.068 & 0.885 \\
$\mathrm{Zn}-65$ & 67.57 & 0.081 & $1.08 \mathrm{E}-03$ & 0.419 & 0.095 & 0.515 \\
Sb-124 & - & 0.052 & $3.78 \mathrm{E}-03$ & 0.010 & 0.007 & 0.021 \\
Ce-144 & 23.65 & 0.024 & $4.05 \mathrm{E}-04$ & - & 0.011 & 0.011 \\
Hf-181 & 6.76 & - & - & - & 0.003 & 0.003 \\
Total & 122.06 & 0.233 & $3.10 \mathrm{E}-02$ & 3.681 & 0.376 & 4.088 \\
Volume & 625 & 200 & 250 & 250 & 250 & - \\
(mL) & 625 & & & & & \\
\hline
\end{tabular}


Table D.3 Gross-alpha measurements on target A leaches

\begin{tabular}{cccccc}
\hline $\begin{array}{c}\text { Leachate } \\
\text { description }\end{array}$ & Bq/mL & $\begin{array}{c}\text { Volume } \\
(\mathrm{mL})\end{array}$ & $\mathrm{Bq}$ & \multicolumn{2}{c}{$\begin{array}{c}\text { Sample dilution } \\
\text { factor }\end{array}$} \\
\hline Target leaches & $<10$ & 250 & $2.5 \times 10^{3}$ & None & 20 \\
\hline Ethanol & 662 & 250 & $1.6 \times 10^{5}$ & None & 20 \\
$0.5 \underline{\mathrm{M} \mathrm{HCl}}$ & 40 & 250 & $10^{4}$ & None & 20 \\
$0.1 \underline{\mathrm{M} \mathrm{HCl}}$ & & & & & 1010 \\
Pellet leaches & & & & & \\
Water-reflux & $8.2 \times 10^{4}$ & 500 & $4.1 \times 10^{7}$ & 101 & 1010 \\
$0.5 \underline{\mathrm{M} \mathrm{HCl}}$ & $4.4 \times 10^{4}$ & 250 & $1.1 \times 10^{7}$ & 101 & 1010 \\
$0.1 \underline{\mathrm{M} \mathrm{HCl}}$ & $2.5 \times 10^{3}$ & 250 & $6.2 \times 10^{5}$ & 101 & 1010 \\
$0.5 \underline{\mathrm{M} \mathrm{HCl}}$ & $1.8 \times 10^{4}$ & 250 & $4.5 \times 10^{6}$ & 101 & 1010 \\
$0.1 \underline{\mathrm{M} \mathrm{HCl}}$ & $4 \times 10^{4}$ & 250 & $10^{7}$ & 101 & 1010 \\
$0.2 \underline{\mathrm{M} \mathrm{HCl}} \mathrm{reflux}$ & $2.1 \times 10^{4}$ & 250 & $5.2 \times 10^{6}$ & 101 & 1010 \\
\hline
\end{tabular}

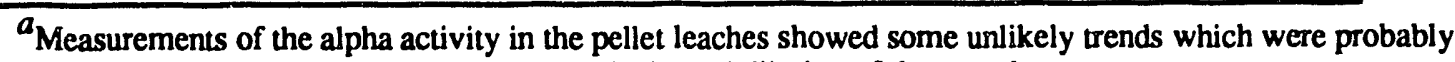
due to cross-contamination associated with the in-cell dilution of the samples. 


\section{INTERNAL DISTRIBUTION}

1. C. W. Alexander

2. D. E. Benker

3. J. E. Bigelow

4. W. D. Bond

5. R. W. Brewer

6. R. R. Brunson

7. F. R. Chattin

8. E. D. Collins

9. L. K. Felker

10. W. Fulkerson

11. R. K. Genung

12. J. M. Keller

13. J. B. Knauer
14. C. L. Ottinger

15. C. E. Porter

16. R. G. Stacy

17. R. M. Wham

18. J. T. Wiggins

19-23. D. F. Williams

24. Central Research Library

25. Y-12 Technical Library Document Reference Center

26. ORNL Patent Section

27-28. ORNL Laboratory Records

29. ORNL Laboratory Records, RC

\section{EXTERNAL DISTRIBUTION}

30. L. W. Boyd, Reactor Operations Division, Department of Energy, Oak Ridge Operations, P. O. Box 2608, Oak Ridge, TN 37831-6390

31. J. E. Brasier, Radioisotopes and Irradiation Services, Idaho National Engineering Laboratory, P. O. Box 1625, Idaho Falls, ID 83415-7133

32. D. E. Erb, Office of Isotope Production and Distribution, U.S. Department of Energy, Mail Stop NE-40, GTN, Washington, DC 20545

33. G. D. O'Kelley, 8228 Corteland Drive, Knoxville, TN 37909

34. Office of Assistant Manager, Energy Research and Development, DOE-OR, P. O. Box 2001, Oak Ridge, TN 37831

35-36. Office of Scientific and Technical Information, P. O. Box 62, Oak Ridge, TN 37831, for microfiche distribution per Category UC-504 

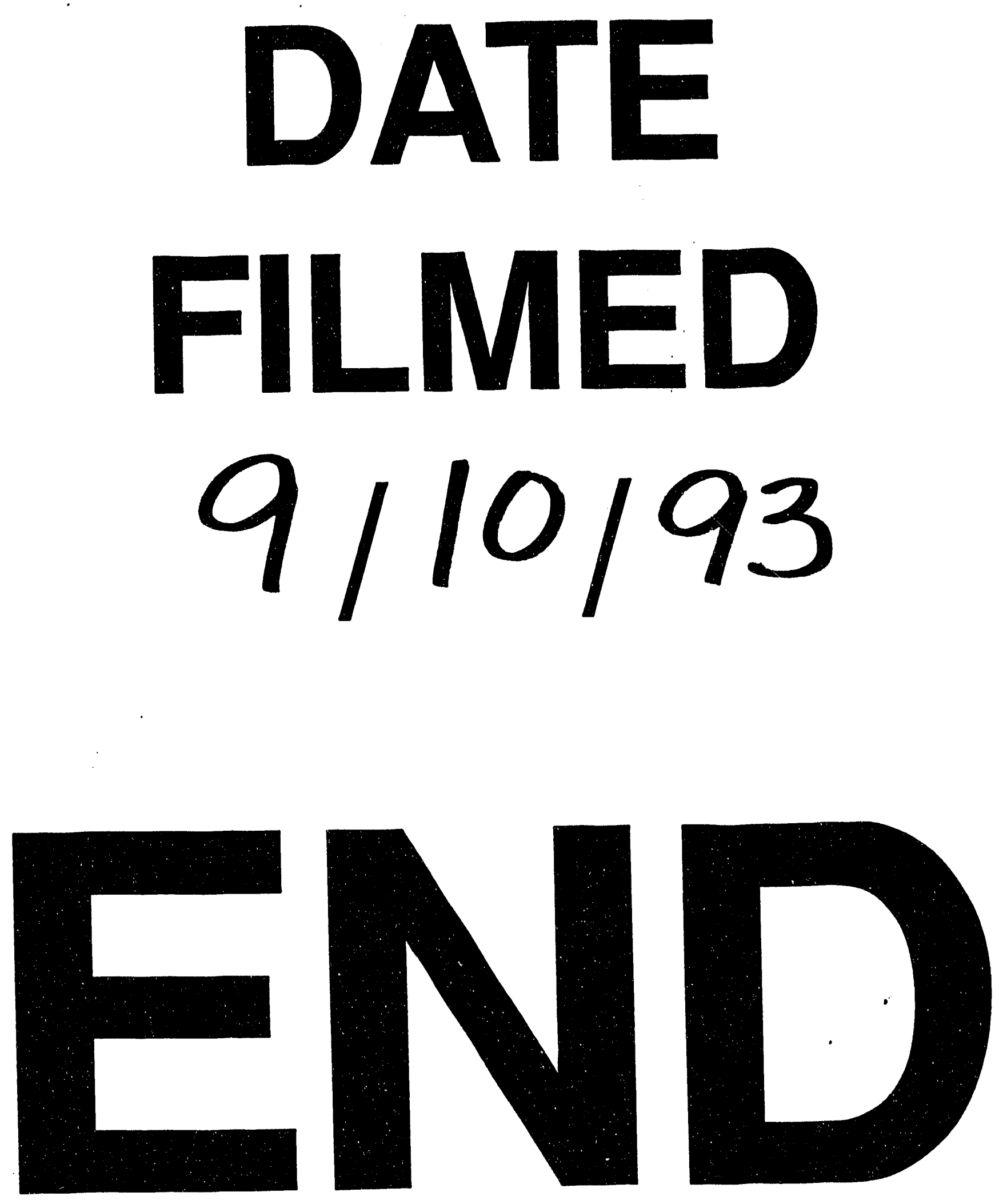
